\title{
Cardiovascular risk factors in elderly
}

With special emphasis on atrial fibrillation, hypertension and diabetes

Karin Rådholm

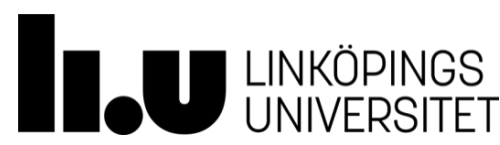

Division of Community Medicine

Department of Medical and Health Sciences Linköping University, 58183 Linköping, Sweden 
C Karin Rådholm, 2015

Cover picture/illustration: Karin Rådholm

Published articles have been reprinted with the permission of the copyright holders.

Printed in Sweden by LiU-Tryck, Linköping, Sweden, 2015

ISBN 978-91-7519-030-3

ISSN 0345-0082 
To Carl, Clara, Axel \& Arvid To Eva \& Kjell 



\section{CONTENTS}

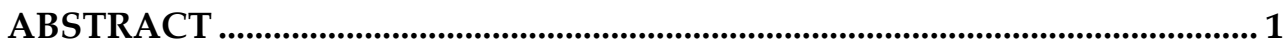

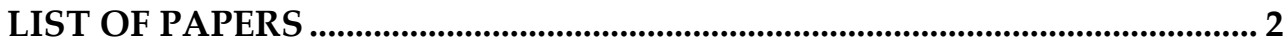

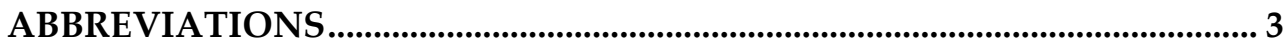

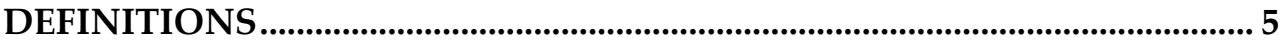

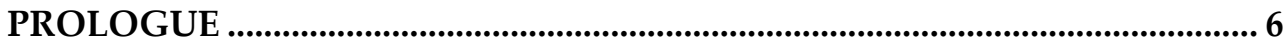

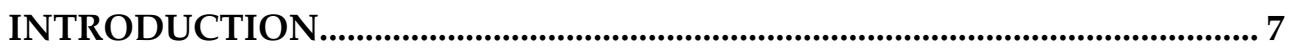

Age distribution world wide .................................................................................. 7

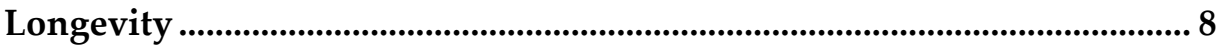

Risk factors for cardiovascular disease....................................................... 8

Risk factor management in primary health care ……................................. 9

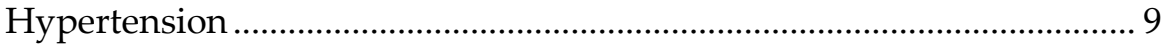

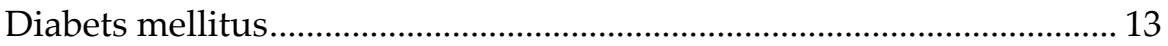

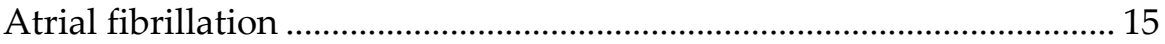

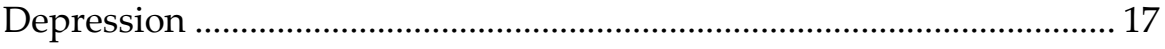

Drugs and ageing ................................................................................................. 18

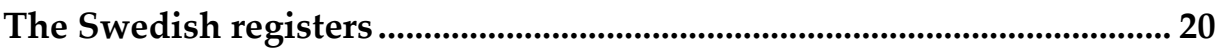

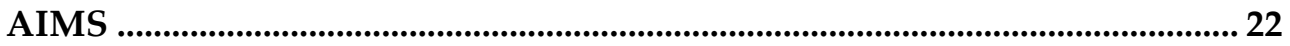

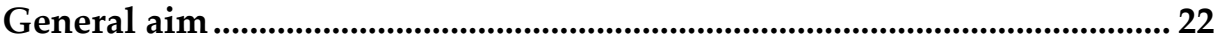

Specific aims ....................................................................................................... 22

MATERIAL AND METHODS ........................................................................... 23

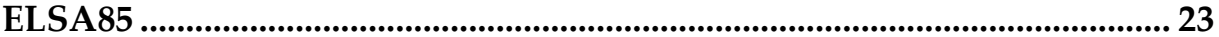

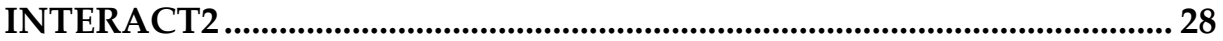

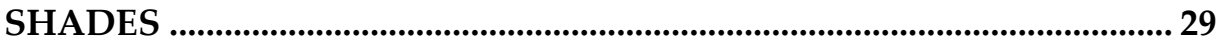

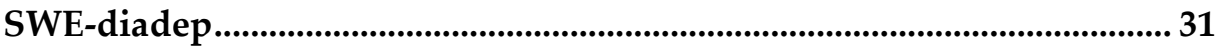

Statistical analyses ............................................................................................. 35 


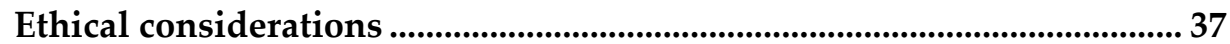

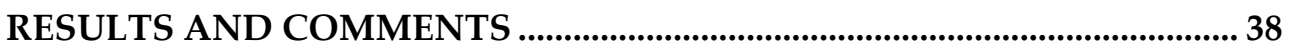

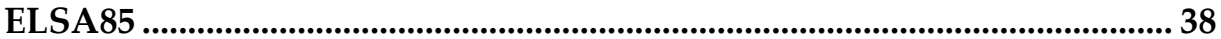

INTERACT2

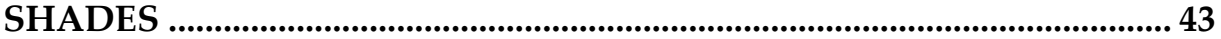

SWE-diadep................................................................................................................ 47

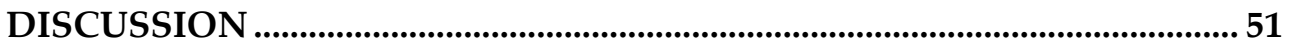

Strengths and limitations .................................................................................... 55

Clinical implications and future research....................................................... 56

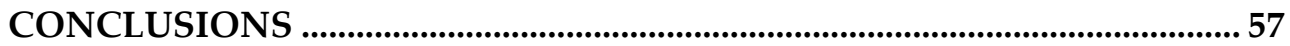

General conclusion ......................................................................................... 57

Specific conclusions ................................................................................................. 57

POPULÄRVETENSKAPLIG SAMMANFATTNING ........................................58

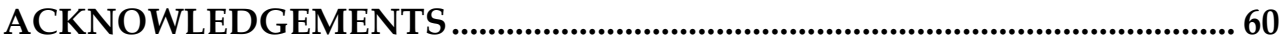

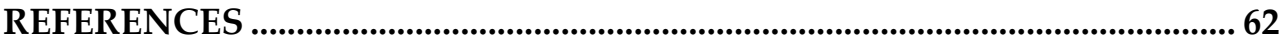




\section{ABSTRACT}

\section{Background}

The part of the population that belongs to the oldest-old (ages 80 years or older) increases rapidly, worldwide. Cardiovascular disease (CVD) is the leading cause of death and disease burden globally. Multimorbidity is common in old age and stroke, diabetes mellitus (DM) and atrial fibrillation (AF) are strongly associated with age. Cardiovascular risk factors are well studied and documented in younger and middle ages, but not as well in old and frail individuals. Therefore, preventive treatment choices are mostly based on evidence for younger patients. The aim of this thesis was to explore age and other aspects of cardiovascular risk factors; $\mathrm{AF}$, hypertension and $\mathrm{DM}$, in relation to comorbidity, cardiovascular outcome and mortality.

\section{Methods}

This thesis was based on four different studies:

o The ELSA85 cohort study of 85 years old in Linköping, Sweden

o The international, multicentre, randomised controlled INTERACT2 trial of spontaneous intracranial haemorrhage (ICH), mean age 64 years.

o The prospective SHADES study of nursing home residents, mean age 85 years.

o The prospective, national SWE-diadep study of dispensed antidiabetics, antidepressants and prevalent myocardial infarction (MI) in 45-84 years old.

Data was obtained from questionnaires (ELSA85, INTERACT2), medical records and medical examination (ELSA85, INTERACT2, SHADES), and national registers (SWE-Diadep).

\section{Results}

The ELSA85 study showed that $16 \%(n=53)$ had an electrocardiogram (ECG) showing AF. There was an increased hazard ratio (HR) for all-cause mortality in participants with AF at baseline, at 90 years of age (HR 1.59, 95\% Confidence Interval [CI] 1.04-2.44) adjusted for sex. This increase in HR did not persist when adjusted for congestive heart failure (CHF). In the INTERACT2 study, increasing age was associated with increasing frequency of death or dependency (odds ratio [OR] 4.36, 95\% CI 3.12-6.08 for $>75$ years vs $<52$ years, p value for trend $<0.001$ ). The SHADES study showed that participants with systolic blood pressure (SBP) $<120 \mathrm{mmHg}$ had an increased HR for mortality $(1.56,95 \%$ CI 1.08-2.27, $\mathrm{p}=0.019)$ but there were no differences between SBP groups $140-159 \mathrm{mmHg}$ and $\geq 160 \mathrm{mmHg}$ compared with the reference group, SBP 120-139 mmHg. SBP decreased during the prospective study period. In the SWE-diadep study, individuals with antidiabetics and antidepressants combined had a greater HR for MI compared to the reference of no antidiabetics or antidepressants, mostly so in women aged 45-64 years (HR 7.4, 95\% CI 6.3-8.6).

\section{Conclusion}

Risk factors for CVDs in elderly differ from cardiovascular risk factors in middle aged individuals and are not associated to disease and prognosis in the same way as in middle aged adults. 


\section{LIST OF PAPERS}

I. Rådholm, K., Östgren, C. J., Alehagen, U., Falk, M., Wressle, E., Marcusson, J. \& Nägga, K. Atrial fibrillation (AF) and co-morbidity in elderly. A population based survey of 85 years old subjects. Archives of Gerontology and Geriatrics, 52(3), e170-175.

doi: 10.1016/j.archger.2010.10.024

II. Rådholm, K., Arima, H., Lindley, R., Wang, J., Tzourio, C., Robinson, T., Heeley, E., Anderson, C.S. \& Chalmers, J. for the INTERACT2 Investigators. Older age is a strong predictor for poor outcome in intracerebral haemorrhage: the INTERACT2 study. Age and Ageing 2014; 0: 1-6. doi: 10.1093/ageing/afu198

III. Rådholm, K., Festin, K., Falk, M., Midlöv, P., Mölstad, S. \& Östgren, C. J. Blood pressure and all-cause mortality: a prospective study on nursing home residents. Submitted manuscript.

IV. Rådholm, K., Wiréhn, A-B., Chalmers, J. \& Östgren, C.J. Use of antidiabetic and antidepressant drugs is associated with increased risk of myocardial infarction: a nationwide register study. Diabetic Medicine 2015 Jun 2. doi: 10.1111/dme.12822 [Epub ahead of print] 


\section{ABBREVIATIONS}

$\begin{array}{ll}\text { AII blocker } & \text { Angiotensin II blocker } \\ \text { AF } & \text { Atrial fibrillation } \\ \text { AHA } & \text { American heart association } \\ \text { ACE inhibitor } & \text { Angiotensin-converting-enzyme inhibitor } \\ \text { ATC } & \text { Anatomic therapeutic chemical system } \\ \text { BMI } & \text { Body mass index } \\ \text { BNP } & \text { Brain natriuretic peptide } \\ \text { BP } & \text { Blood pressure (used in Figure 3) } \\ \text { CHADS }_{2} & \text { Congestive heart disease, Hypertension, Age } \geq 75 \text { years, } \\ & \text { Diabetes, previous Stroke }\end{array}$

$\mathrm{CHA}_{2} \mathrm{DS}_{2}-\mathrm{VASc}$ Congestive heart disease, Hypertension, Age $\geq 75$ years, Diabetes, previous Stroke, Vascular disease, Age 65-74 years, female Sex

$\mathrm{CHF} \quad$ Congestive heart failure

CI Confidence interval

CRP C-reactive protein

CT Computed tomography

CVD Cardiovascular disease

DBP Diastolic blood pressure

DM Diabetes mellitus

ECG Electrocardiogram

eGFR Estimated glomerular filtration rate

ELSA85 Elderly in Linköping screening assessment

EQ-5D European Quality of Life - 5 Dimensions

GI Gastrointestinal

GFR Glomerular filtration rate

GP General Practitioner

$\mathrm{Hb} \quad$ Haemoglobin

HbA1c Haemoglobin A1c, glycated haemoglobin

HR Hazard ratio

HRQoL Health related quality of life

ICD-10 The international classification of diseases, 10th version

ICH Intracranial haemorrhage

INTERACT2 The second INTEnsive blood pressure Reduction in Acute Cerebral haemorrhage Trial 
LVH Left ventricular hypertrophy

MI Myocardial infarction

MMSE Mini Mental State Examination

MNA Mini Nutritional Assessment

mRS Modified Rankin Scale

NIHSS

National Institutes of Health Stroke Scale

NSAID

Nonsteroidal anti-inflammatory drug

NT-proBNP N-terminal of the prohormone brain natriuretic peptide

NOAC

Novel oral anticoagulant

OAC

Oral anticoagulant

OR

Odds ratio

PHC

Primary health care

SBP

Systolic blood pressure

SHADES Study on Health And Drugs in Elderly in nursing homes in Sweden

SSRI

SU

Serotonin reuptake inhibitor

SWE-diadep The SWEdish diabetes and depression study

TCA

TIA

Tricyclic antidepressant

TSH

Transient ischemic attack

VAS

Thyroid stimulating hormone

WHO

Visual analogue scale

World health organization 


\section{DEFINITIONS}

Comorbidity Presence of one or more additional disorders/illnesses.

Elderly Generally a description of individuals 65 years old or older. In this thesis the term elderly is used for the study participants that were in their 80 s.

Frailty A concept of biological ageing and decline of physiological functions.

GP General Practitioner. In the Swedish educational system it takes 21 months as a 'Pre-registration house officer' after graduation from university, and after that a specialist training as a GP registrar for 5 years, approximately half of that time in hospital clinics.

Middle age The best years of our life? Before old age and after young adult age.

Multimorbidity More than two chronical illnesses.

Old age

A chronological age concept used synonymously with elderly.

Older

As with 'elderly' or 'old age'. From a global perspective the term older people are sometimes used from 60 years of age.

Oldest old Individuals 80 years old or older.

Stroke Intracranial haemorrhage or ischemic infarction. 


\section{PROLOGUE}

During my time as a GP (general practitioner) registrar in general practice I met many patients who had consulted several specialists in hospital and received a variety of treatments for many different conditions. These pharmacological treatments were up to date and in accordance with current guidelines, but resulted in polypharmacy and unwanted side effects. I met elderly patients in nursing homes and almost all of them were prescribed several different medicines for treatment of cardiovascular risk factors. This phenomenon inspired my research studies. Is it really wise to treat elderly patients with co- and multimorbidity according to the same guidelines as for middle aged patients? What is known about cardiovascular risk factors and their treatment in the very elderly with multimorbidity?

I met Dr Katarina Nägga at the Geriatric department of Linköping's University Hospital and gladly accepted to be part of the ELSA85 study. I also met Professor Carl Johan Östgren (associate professor at that time) and with his encouragement and guidance I wrote my first paper. After that I enrolled as a PhD student at Linköping University in April 2011.

I have not regretted becoming a PhD student, and during my PhD studies I have come to realise just how important scientific training and clinical research is to patient care in all specialist categories, general practice not excluded. My desire is to keep on learning, to become as versatile as possible and, as good a GP as I can be. 


\section{INTRODUCTION}

\section{Age distribution world wide}

The part of the population that belongs to the oldest old (ages 80 years or older) increases rapidly worldwide and is predicted to do so continuously. This is mainly due to socio-economic development and advances in medicine with reduced mortality from infectious diseases and to some extent also noncommunicable diseases[1,2]. The expected increase in the number of older persons (aged 60 years or over) globally, is more than doubled between 2013 and 2050, from 841 million people in 2013 to more than 2 billion in 2050[2].

Between 1950 and 2050, the predicted increase of persons 80 years or older is $1450 \%$ in developed regions and $4367 \%$ in less developed regions[2]. The overall global population growth is slower, from 7.2 billion in 2013 to an expected number of 9.6 billion in 2050. Sweden is no exception to this pattern and the Swedish population pyramid looks more like a mushroom in 2013, with many elderly and fewer children, than the pyramid shape it had a hundred years ago (Figure 1)[3].

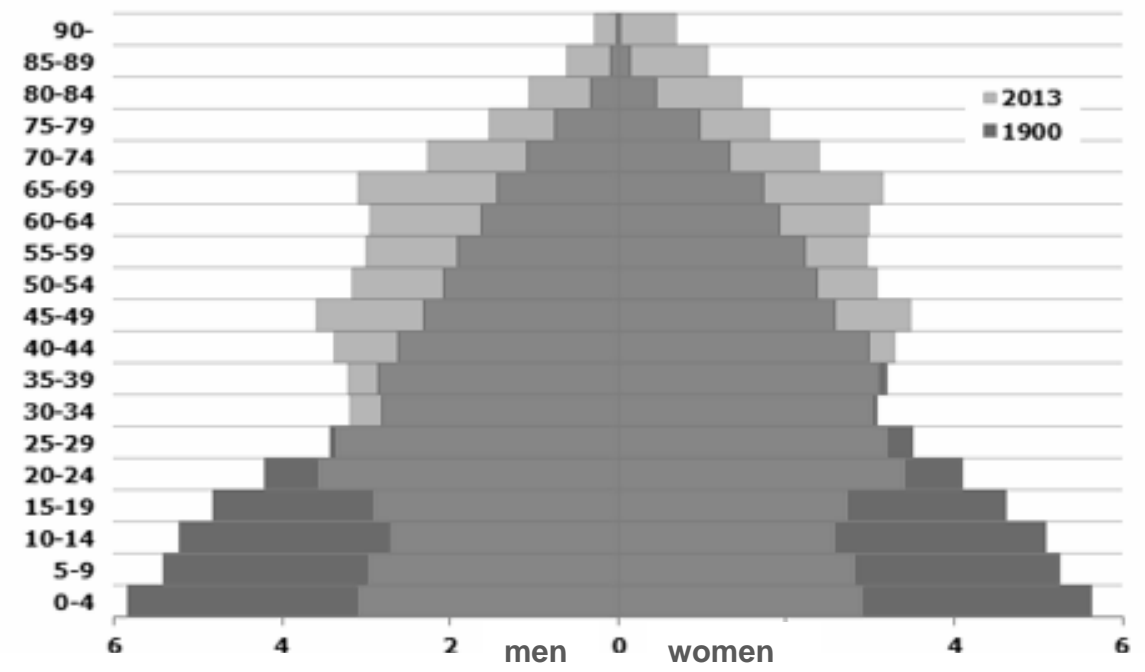

Figure 1. The Swedish population pyramid. Ages 0 to 100 years and parts of the entire population are shown in five year age groups for December 1900 (black) and December 2013 (light grey). Source: Statistics Sweden, Population statistics. http://www.scb.se/en, 2014. 


\section{Longevity}

The determinants for longevity are both environmental and genetic, the latter poorly understood[4]. Among the exceptionally aged, age-associated disease onset and physical and mental decline occur much later[5]. In the genetically isolated population of Okinawa, Japan, people grow exceptionally old. Cardiovascular diseases (CVD) are rare and does not appear clinically until advanced age, even 100 years or older in people reaching age 110[6, 7]. The offspring of centenarians (people that live to become 100 years) have cardiovascular advantages and reduced prevalence of both CVDs and CVD risk factors[8]. Studying the oldest old means that there has already been a selection, some people does not live to see old age while others in better health do.

\section{Risk factors for cardiovascular disease}

CVD is the leading cause of death and disease burden globally, an estimated 17.3 million people died from CVDs in 2008[9]. The prevalence of chronic illnesses is rising continuously, first and foremost due to population ageing. The CVDs such as stroke, diabetes mellitus (DM) and atrial fibrillation (AF) are strongly associated with age[1, 10]. Preventable cardio-metabolic risk factors are responsible for more than $60 \%$ of worldwide deaths from CVDs, $\mathrm{DM}$ and chronic kidney disease. High blood pressure, $\geq 140 / 90 \mathrm{mmHg}$, is the most important. Prehypertension, a blood pressure of $120-139 / 80-89 \mathrm{mmHg}$ is also a risk factor for CVDs, haemorrhagic- and ischemic stroke included[11, 12]. Other leading preventable risk factors are; high blood glucose, high cholesterol and adiposity[13]. The mortality burdens of high body mass index (BMI) and high glucose have increased faster than that of high cholesterol. However, high serum cholesterol remains the second leading risk factor for deaths from ischaemic heart disease[13]. Multimorbidity is common in old age[14, 15] and cardiometabolic multimorbidity (DM, stroke and myocardial infarction [MI]) has been shown to multiplicatively increase the mortality risk and thus substantially lower life expectancy[16].

Smoking, alcohol use and physical inactivity are major preventable risk factors for CVDs[17, 18]. More than $10 \%$ of all CVD deaths worldwide are due to smoking[19]. There are important socio-economic determinants linked to a 
high prevalence of CVD risk factors. Low education, low income, poverty and unemployment are associated to more prevalent and higher mortality rates from CVDs compared to people with higher education, higher income and low rates of unemployment[20-22].

\section{Risk factor management in primary health care}

Primary health care (PHC) is central to risk factor management for CVD and DM. Structured life-style assessments and interventions are used to a various extent, for example to stimulate to regular physical activity. Physically active persons have less atherosclerotic and metabolic risk factors for CVDs and live longer than physically inactive individuals[23]. There is a need for population based as well as individual prevention programs in PHC[23, 24]. Several risk calculation instruments are available to assess the overall CVD risk, for example The Framingham Risk Score, UKPDS Risk Engine and SCORE, where the latter is customised for Swedish conditions[25]. These instruments can be used for clinical guidance and also to illustrate CVD risk factors to the patient. PHC is also an important caregiver to patients with chronical illness, CVDs included. One third of the chronically ill patients are seen only by their GP, with no other secondary care contacts over a year[26].

\section{Hypertension}

\section{Hypertension - history}

A BP, blood pressure measurement was done for the first time in the 1700 s. The British scientist Stephen Hales $(1677$ - 1761) experimented with invasive arterial blood pressure measurements on a horse. In 1827, a pathologist, Dr Richard Bright (1789-1858) described the hypertensive heart[27] and seventeen years later that hypertension was caused by renal disease[28]. Over the next half-century several researches demonstrated that hypertension may occur without overt renal disease and also may precede arteriosclerosis[28]. The mercury manometer was introduced in 1828 by the French physicist Jean Poiseuille (1797 - 1869), but it was not until the second half of the 1800s that non-invasive measurements were possible[29]. Some practitioners accepted and valued the use of the sphygmanometer when it was introduced in the late 1800 s and early 1900s, but many clinicians were initially sceptical claiming that 
'we pauperize our senses and weaken clinical acuity'[28]. In the 1920s it was found that 'mortality increases rapidly with the increase in blood pressure over the average'[28] and the Swedish researcher, Eskil Kylin (1889-1975), described the association of hypertension with hyperglycemia and gout in 1923[31]. Initially no antihypertensives were available and sedatives together with dietary advice, such as salt reduced rice, were recommended[30, 32]. Cardiologist William Evans (1895-1988) noted in the textbook Cardiology in 1948 that 'The blood pressure is [considered to be] raised when the systolic blood pressure is 180 or over, and/or the diastolic pressure is 110 or over, on three consecutive examinations, and in the presence of clinical, radiological and cardiographic evidence of cardiovascular hypertrophy'[32] . In the 1940s surgical sympathectomies and adrenal-ectomies were performed to treat malignant hypertension, the latter with a surgically induced Mb Addison as a side effect[30]. The medical community was sceptical to antihypertensive treatment initially, and several well-known cardiologists advised against antihypertensive treatment in the 1930s[28]. The first antihypertensive agents were nitrates and thiocyanates among others and thiazide-type diuretics and spironolactone were discovered in the late 1950s[28, 32]. In the 1960s and 1970s, many experts still believed that hypertension was a natural process of ageing, and that the normal systolic blood pressure (SBP) level was 'age + 100'. The Framingham Heart Study, begun in 1949, reported in the 1960s that there was a strong correlation between hypertension and cardiovascular endpoints; myocardial attacks, stroke and congestive heart failure (CHF)[33]. Almost every large clinical trial has shown that the lower the BP, blood pressure, the better the outcome and today's management of hypertension is a major success in preventive medicine[32].

\section{Hypertension and ageing}

Hypertension is a major risk factor for haemorrhagic stroke[34] and the prevalence of hypertension increases with age. In the Framingham Heart Study, $85 \%$ of the non-hypertensive middle aged population at baseline developed hypertension during 20-25 years of follow-up [35]. The gradual increase in SBP by ageing occurs due to arterial stiffness; decreased blood vessel distensibility, increased thickness of the intima media and endothelial dysfunction [36]. Baroreceptors become insensitive and requires a large blood pressure change to compensatory raise the heart frequency, and thus confers an increased risk for hypotension and decreased cerebral perfusion[37]. A 
slow baroreceptor response is also more likely to cause an orthostatic hypotension following the use of a vasodilating drug in older persons[38].

In international, American and European guidelines on hypertension management, the recommended goal for hypertension treatment is less than $140 / 90 \mathrm{mmHg}[39,40]$. The recent guidelines recommend reducing SBP to between $140 \mathrm{mmHg}$ and $150 \mathrm{mmHg}$ or $<150 \mathrm{mmHg}$ in individuals older than 80 years whose SBP is $160 \mathrm{mmHg}$ or higher[38, 39]. However, the evidence derived from randomized controlled trials on the beneficial effects of reaching this treatment goal is scarce in older patients with hypertension[41, 42]. GPs accept higher blood pressure levels than recommended in guidelines, especially in older patients [43]. In the HYVET study on patients aged 80 years or older, the blood pressure target was $<150 / 90 \mathrm{mmHg}$. It was concluded that treatment of hypertension was beneficial also in this age group [44]. However, the effect of reaching the blood pressure treatment target was not evaluated in frail older people with hypertension due to exclusion criteria such as clinical dementia and the need for nursing care. In frail, elderly patients a low SBP has been associated to worse outcomes[10, 42, 45, 46]. Furthermore, there is an association between low SBP and greater prevalence of dementia [47-49].

\section{Treatment of hypertension in old individuals}

Antihypertensives should, if possible, be given as a monotherapy when hypertension treatment is started in elderly patients. In general, patients older than 80 years should not be given more than two[50] to three[38] antihypertensive medications.

In the current hypertension treatment guidelines (the European Society of Hypertension/the European Society of Cardiology, the American Society of Hypertension and the International Society of Hypertension) there are no recommendations about withdrawal of antihypertensives if a patient has excessively low blood pressure levels[39, 40]. At present, it is not universally accepted to what blood pressure levels elderly and frail individuals should be treated.

There is little evidence from controlled studies comparing different antihypertensive drug regimens in very old patients. This applies to lifestyle changes as well, where some lifestyle changes such as weight loss without 
physical activity[38,51] or reduced salt intake even might be damageable to the old and frail patient[38].

Calcium channel blockers and thiazide diuretics are first-line drugs in frail older antihypertensive patients[38, 42]. The common side effect of lower limb edema for calcium blockers should not be mistaken for CHF. Most common side effects of thiazide diuretics are hyponatremia, hypokalemia, hyperglycemia and possible DM type 2 onset. Also, hypotension, dehydration, hyperuricemia and gout attacks may occur[38]. In old individuals with hypertension special treatment considerations should be made:

- Aldosterone antagonists are contraindicated in severe renal failure, estimated glomerular filtration rate (eGFR) $<30 \mathrm{~mL} / \mathrm{min} / 1.73 \mathrm{~m}^{2}$, eGFR and electrolytes should be monitored after any dose change in an older patient[38].

- Diuretics and angiotensin-converting-enzyme inhibitors (ACE inhibitors)/ angiotensin II blockers (AII blockers) should not be doseincreased in the same time to avoid worsening of renal function[38].

- ACE inhibitors/AII blockers should also be avoided if dehydration is suspected[38].

- Beta-blockers are indicated for CVD and are not a first option for hypertension treatment[52]. In old patients there is a severe risk of bradycardia, interactions with Alzheimer treatment (acetylcholinesterase inhibitors) and risk of accentuated fatigue, depression and confusion with beta-blocker treatment[38, 53].

- Alfa-inhibitors are rarely indicated and these are associated with increased risk of delirium, confusion and aggravated depression as well as orthostatic- and post prandial hypotension[38].

- Loop diuretics are only indicated for hypertension treatment if there is a severe renal failure, eGFR $<30 \mathrm{~mL} / \mathrm{min} / 1.73 \mathrm{~m}^{2}$, or for comorbid CHF treatment. Loop diuretics have several down faults for the aged and frail patient, it reduces extra cellular volume and potent other fluid soluble drugs, there is an increased risk for hypovolemia and hypo-perfusion of vital organs[36, 54]. Also, loop diuretics combined with selective serotonin reuptake inhibitor (SSRI) antidepressants constitutes a risk for severe hyponatremia[38]. Furthermore, there is a risk for non-adherence or social isolation due to the increased risk of incontinence[38]. 


\section{Diabets mellitus}

\section{Diabetes - brief history}

Diabetes has been known to physicians for thousands of years. Ancient Egyptian papyrus rolls from 1550 BC describes a polyuric state[55] later interpreted as an early description of DM. The term diabetes was founded in the ancient Greece, by the physician Aretaeus of Cappadocia (circa the first century). Metformin is now days the most prescribed oral treatment for DM. It originates from a botanical compound, the French lilac (Galega officinalis) that was used from medieval times and onwards to treat plague, worms, snakebites, miasma and dysuria[56]. In 1921 Fredrick Banting (1891-1941) and Charles Best (1899-1978), together with John J.R. Macleod (1876-1935) and James Collip (1892-1965), discovered insulin and the first patient was insulin treated in 1922[55].

\section{Diabetes mellitus in elderly persons}

$\mathrm{DM}$ is another major risk factor for cardiovascular events, such as MI or stroke[57] and women with DM are at especially high risk for coronary heart disease[58]. In 2014, 9\% of adults over 18 years of age worldwide had DM and in the year $2012 \mathrm{DM}$ accounted for the death of 1.5 million people, out of which more than $80 \%$ in low-income countries[59]. Type 2 DM constitutes $90 \%$ of all DM[59, 60]. The prevalence is continuously rising[61], at large due to unhealthy living with physical inactivity and excess body fat[59]. The DM prevalence varies greatly between countries and populations, in Sweden, it is approximately $4.7 \%[62]$. There is a rise in the Swedish DM prevalence with ageing to $14-17 \%$ in elderly 75 years and over[63]. The increase in Type 2 DM with age can be explained by several different factors; pathophysiological changes with reduced glucose dependent insulin release and increased insulin resistance, decreased physical activity and abdominal obesity[64]. Some commonly used medications elevate glucose levels and can induce hyperglycemia, for example thiazide diuretics, beta-blockers, NSAIDs (nonsteroidal anti-inflammatory drugs) and glucocorticoids[64].

Impaired glycaemic control in patients with DM confers an increased risk for vascular illness. A multi-factorial risk factor management is essential to prevent macrovascular complications[57]. A tight glucose control is however 
doubtful in aged and frail patients with DM due to the risk of harmful hypoglycaemias and a remaining short life-expectancy, thus low benefits from long term preventive treatments[65, 66]. There is a J-shaped curve for Haemoglobin A1c (HbA1c) values in relation to mortality, low and high mean $\mathrm{HbA1c}$ values are associated with an increased mortality risk[67, 68]. Severe hypoglycaemia is associated with poor outcomes. There is an increased risk of macrovascular events, microvascular events and death from all causes[69]. Cardiac arrhythmias may be caused by hypoglycaemic events[70] and hypoglycaemia worsens cognitive function[71]. This is especially concerning in old, frail patients prone to confusion. Symptoms of hypoglycaemia in elderly patents are often unspecific and, therefore difficult to interpret[64]. Also, typical symptoms of hyperglycaemia are less common in elderly persons due to an increased renal threshold for glycosuria and subsequently not polyuria. There is less polydipsia due often impaired thirst mechanisms as well[64].

\section{Treatment of diabetes mellitus in elderly}

According to Swedish guidelines, the treatment goal for HbA1c in elderly, frail individuals are $55-70 \mathrm{mmol} / \mathrm{mol}[71]$ and pharmacological treatment to reach $\mathrm{HbA1c}$ values less than $50 \mathrm{mmol} / \mathrm{mol}$ should be avoided[66]. There is a number of oral antidiabetics of which metformin is the most commonly used, also in elderly people. In monotherapy, the risk of hypoglycaemia is low, but there is a risk of lactate acidosis in patients with renal impairment[64]. The second most used category of oral agents are the Sulfonylureas (SU) that stimulate pancreatic insulin secretion and there is a risk of prolonged and severe hypoglycaemia in elderly patients with SU treatment[64, 71], which may require admittance to hospital[71]. Insulin treatment is recommended for patients in nursing homes, particularly long-acting insulins because of an even profile that reduces the risk for hypoglycaemias, compared to intermediateacting insulins[64]. 


\section{Atrial fibrillation}

\section{Atrial fibrillation - brief history}

Pulse measurements have been carried out and described for thousands of years. Possibly, the earliest description of AF dates back to an emperor physician in China, approximately 2600 BC. Most ancient physicians acknowledged a poor prognosis associated with irregular pulse. In 1628, William Harvey (1578 - 1657), a British physician published a book on the motion of the heart and the blood describing 'fibrillation of the auricles' of the dying animal heart[72]. In 1785 William Withering (1741-1799), an English botanist and physician, discovered the therapeutic properties of the digitalis leaf (Digitalis purpurea) and noted that a patient with weak and irregular pulse improved to have a more full and regular pulse beat[73]. Warfarin (vitamin $\mathrm{K}$ inhibitor) has until recently been the only available oral anticoagulant $(\mathrm{OAC})$ for prevention of ischemic stroke, in clinical use for more than 60 years[74].

\section{Atrial fibrillation and elderly}

AF prevalence increases with age and has previously been shown to be between 9 and $18 \%$ in $\geq 80$ years old compared to about $0.5 \%$ in the ages $50-59$ years[75, 76]. Fibrosis of the heart associated with ageing (and in patients with structural heart disease) is an important pathophysiological factor for AF[77]. Other risk factors for developing AF are[75, 78-81]:

- High SBP

- Prior MI

- Valvular heart disease and left atrial enlargement

- Hyperthyroidism

- Overweight

- Excessive use of alcohol

- Male gender

Furthermore, AF is associated to DM $[82,83]$, decreased glomerular filtration rate (GFR) [84, 85] and sleep apnoea[72]. Regular physical activity has been shown to lower the risk of developing AF in older adults [78] even though excessive endurance exercise increases the risk for AF in younger adults[86, 
87]. There are three forms of AF; paroxysmal-, persistent- and permanent AF. The latter is associated to worse outcomes[88]. There is a slow progression over time from paroxysmal- or persistent $\mathrm{AF}$ to permanent $\mathrm{AF}$, in which ageing plays a major role due to the progression of atrial fibrosis associated with ageing[77]. AF is associated with a five times greater risk of cardio embolic stroke [89, 90], which increases in old age [91, 92]. Old patients with $\mathrm{AF}$ have a sixteen times increased stroke risk compared to middle aged AF patients[93].

\section{Stroke prevention in elderly}

Prophylactic oral anticoagulation (OAC) treatment prevents atrial blood clotting and reduces the risk for ischemic infarction in AF patients with approximately two-thirds[94]. OAC treatment remains widely under-used in clinical practice in elderly AF patients[95, 96]. It has been shown that the benefits of OAC are of great importance especially for an older patient[97-99]. Risk of major bleeding is hard to estimate and fear of this, drug interactions and dementia are potential influences on a clinician's decision to anticoagulate an elderly AF patient[95]. However, OAC appears to be protective in terms of stroke, MI and death also in patients with a high risk of falling and multiple stroke risk factors[100, 101]. In the Birmingham Atrial Fibrillation Treatment of the Aged Study, BAFTA, it was shown that the bleeding risk associated with warfarin treatment in AF patients over 75 years old was not greater than in those treated with aspirin $75 \mathrm{mg}$ daily[102]. Similarly, it has recently been shown that the incident rate of major bleeding was not higher in patients with $\mathrm{AF}$ and warfarin treatment aged 85 or over than younger patients with $\mathrm{AF}[96]$. Also, OAC treatment has been shown to be as effective in people aged 85 years or over as it is in younger people in preventing cardio embolic strokes[102].

Warfarin is well studied, the effect can be monitored via a biomarker (INR) and is reversible with an antidote if needed[74]. There are however disadvantages with warfarin treatment; a large number of interactions with drugs and herbals, K-vitamin intake via different foods, interaction with alcohol[94], multiple blood samples and high monitoring costs[72]. Elderly patients are generally more sensitive to warfarin than younger patients. This is possibly a result of decreased liver mass with impaired capacity to eliminate warfarin as well as reduced production of clotting proteins[74]. 
Since 2009, there is an alternative to warfarin, novel oral anticoagulants (NOAC)[103]. The three available NOACs apixaban, rivaroxaban and dabigatran have been in clinical use for the last few years[72], and have been shown to be as effective or possibly even more so than warfarin in AF patients aged 75 years and above[104]. The major advantage of NOACs over warfarin treatment is the fixed dosage, no requirement of monitoring and rapid action onset[105]. Dabigatran has a lower overall bleeding risk in patients $<75$ years, but in patients $>75$ years the extra cranial bleeding risk is similar or higher to that of warfarin treatment[106]. A retrospective 'real life' study showed that the bleeding risk was increased for dabigatran users compared to warfarin users especially for gastrointestinal (GI) hemorrhage[94, 105]. Ageing markedly increases the risk for GI hemorrhage and the incidence increases 200 -fold from age 30 to age 90 years. For both rivaroxaban and apixaban there are risks of drug interactions, for example with ketoconazole and verapamil[105].

\section{Depression}

\section{Depression - brief history}

In old medical beliefs, disease was caused by an imbalance in one or more of the four bodily humors. Melancholia, or 'fears and despondencies if they last a long time', was described by Hippocrates in the second century BC. It was thought that melancholia was caused by an excess of black bile from the spleen, thus the name derived from Ancient Greek which means dark or black bile. During the middle ages psychiatric illness was thought to be caused by possession by the devil and treatments included religious exorcism. In the 1700s hot and cold baths and chock treatments were administrated, and in the early 1900s opium was used as a sedative. The fist effective antidepressant treatment was electroconvulsive therapy, which was available in the 1930s. In the mid-1950s the tricyclic antidepressants (TCAs) were discovered. The SSRIs were discovered in the 1980s and widely used from the 1990s[107].

\section{Depression in elderly}

Depression is a common condition in somatic chronically ill patients[108]. The prevalence for depression in old age is $12-15 \%[109,110]$, and the prognosis 
and outcomes are worse in older patients with depression compared to younger adults[111, 112]. Late-life depression is defined as a major depressive disorder in adults 60 years of age or older[112], and depression is a risk factor for vascular and neurological illness such as DM, MI, stroke and Parkinson's disease[113]. Individuals with depression have a doubled risk for dementia compared to those without depression[113]. Depression following stroke is common, with a reported prevalence ranging from $25 \%$ to $79 \%[114]$.

\section{Antidepressants in elderly patients}

Data on safety and efficacy in older populations are scarce or absent for many antidepressants. Treatment decisions are therefore often based on data from younger adults[112]. Antidepressants have been reported to affect glycaemic control and to trigger the onset of type 2 DM[115-119]. It is difficult to differentiate between the possible diabetogenic side effects of antidepressants per se (such as weight gain), from the effects associated with the depressive disorder[116, 119]. SSRIs have been reported to confer a glucose lowering effect[117, 120] and animal model studies have reported glucose increment from TCAs[121]. However, results from a longitudinal register study over 8 years shows that SSRIs and TCAs did not affect glycaemic control[121]. In old patients antidepressant treatment has become more common for treatment of agitation, replacing antipsychotics in elderly with dementia and psychosis, in order to diminish risk of stroke and other side effects associated with antipsychotics[122].

\section{Drugs and ageing}

Elderly respond differently to drugs due to an age-dependent change in body composition and a decline of physiological functions [49, 53]. Pharmacokinetics alters in ageing:

- Most importantly because of reduced renal function and impaired ability to excrete metabolized drugs. Also, to some extent altered liver function and reduced capacity for metabolizing drugs[54].

- Drug absorption is difficult to study and there is no evidence of affected GI drug absorption in healthy elderly persons compared to younger. However, $25 \%$ of individuals over 70 years have atrophic gastritis. Low, 
or absence of hydrochloric acid in the ventricle can negatively affect drug absorption from the GI tract in drugs that depend on a low ventricular $\mathrm{pH}$-value for absorption[49, 123], for example the NOAC dabigatran[94]. Also, old people have slower ventricular depletion times compared to young and GI-tract blood circulation diminishes by up to $40 \%$ with ageing[54].

- Habitual changes:

o Overall increasing adipose tissue and the subsequently increased volume of distribution for lipophilic drugs affect the half-life elimination of pharmaceuticals leading to prolonged time until a steady state situation for a particular drug is reached[36, 54].

o In contrary the body water reduces with age, reducing the volume of distribution for hydrophilic drugs. Thus, equal hydrophilic drug doses as in younger individuals will result in higher plasma concentrations in older. Diuretics, especially loop-diuretics, reduces the extracellular water which further reduces the distribution volume for hydrophilic drugs[36, 54].

o Muscle mass decreases in both women and men with approximately $50 \%$ with age[124]. Some drugs are bound to the muscle mass, and in aged patients these drugs will have higher blood concentrations following the loss of binding possibilities, for instance digoxin[54].

Polypharmacy is a frequent problem in elderly patients and drug-related problems, such as adverse drug reactions, drug-drug and drug-disease interactions, and non-adherence are directly correlated with the number of drugs the patient is taking[38]. Geriatric patients suffer from adverse drug reactions more frequently than middle aged adults, because old people are more susceptible to drug effects. This is partially due to multimorbidity and polypharmacy, but also to the age-dependent decline in physiological functions and altered body composition[125]. Nutritional status also has an influence on the drug metabolism rate which diminishes markedly in frail elderly patients[126, 127]. Due to these age-related pathophysiological changes several drugs have been known to cause confusion in old patients, including cardiovascular drugs. For example digoxin can cause cognitive adverse effects even in therapeutic blood levels in old patients and the risk of accumulation increases with decreasing kidney function. Furthermore, beta blockers might cause confusion in old patients[53, 128, 129]. 
Little is known about how pharmacodynamics is affected by ageing. There are significant interpersonal differences for a start and pharmacodynamics are difficult to study[54, 130]. However, pharmacodynamical changes with ageing have been observed for a number of cardiovascular drugs. Verapamil has an increased antihypertensive effect, beta-blocking agents have decreased antihypertensive effects, furosemide has a decreased peak diuretic response and vitamin $\mathrm{K}$ antagonists have an increased anticoagulant effect[130].

There has been a positive change in the trend of inappropriate drug therapy prescription in Sweden between 2006 and 2013, but excessive polypharmacy defined as ten or more concomitant prescribed drugs has not decreased. Currently $10 \%$ of the total Swedish population ages 65 years or above has ten or more drugs[131].

\section{The Swedish registers}

Today, the Nordic countries are unique in the world in terms of comprehensive population registers. Historically, the earliest register of households and individuals has been dated to the Han Dynasty in China in the second century $\mathrm{BC}[132]$. Other historical population registers are the biblical Christmas gospel and an Italian early $14^{\text {th }}$ century population register[133], to mention a few. A Swedish national registration in parish registers was first mentioned in 1571[133]. In 1686 there was a national regulation imposing clergymen to keep parish registers. At that time, if you wanted to move from one village to another, a letter from the clergyman was needed that contained a description of the personal characteristics. This was to be given to the next village clergyman who was to document it in the parish register. All arrivals and departures to and from the parish were registered. Also, legitimate and illegitimate children with their date and place of birth, the date of christening, parents' names and those who had married or died were documented[132]. In 1749 the first general population count was performed and there has been official printed national population statistics since the early 1800s[3]. The personal identification numbers were taken into use in the 1940s and in 1967 they were converted to today's system with date of birth followed by four individual numbers[133].

The main purpose of a population register is to identify all individuals. It also provides aggregate data about the entire population, making it possible to 
implement and monitor a wide range of public measures and planning policies[132]. Apart from the national Cause of Death Register, five national medical registers are held by the National Board of Health and Welfare:

- The National Cancer Register

- The Swedish Prescribed Drug Register

- The National Patient Register (secondary care diagnoses only)

- The Medical Birth Register

- The Dental Health Register 


\section{AIMS}

\section{General aim}

To explore age and other aspects of cardiovascular risk factors; atrial fibrillation (AF), hypertension and diabetes mellitus (DM), in relation to comorbidity, cardiovascular outcome and mortality.

\section{Specific aims}

- To explore and compare prevalent comorbidity and self-estimated health related quality of life in elderly with atrial fibrillation (AF) compared to elderly with sinus rhythm or pacemaker.

- To assess if older age at intracranial haemorrhage (ICH) onset leads to worse disabilities compared to younger ICH patients.

- To assess the blood pressure at baseline and the prospective development of blood pressure over time and relation to mortality in nursing home residents.

- To explore the gender- and age-specific risk of developing a first myocardial infarction (MI) in people treated with antidiabetic and/or antidepressant drugs compared to people with no antidiabetics or antidepressants. 


\section{MATERIAL AND METHODS}

The studies in this $\mathrm{PhD}$ thesis are based on data from participants in three population studies and one register study; ELSA85 (Elderly in Linköping Screening Assessment), SHADES (Study on Health And Drugs in Elderly in nursing homes in Sweden), INTERACT2 (the second INTEnsive blood pressure Reduction in Acute Cerebral haemorrhage Trial) and SWE-diadep (the SWEdish diabetes and depression study).

Two months of the doctoral education was spent at the George Institute for Global Health in Sydney, Australia. This opportunity was partly founded by, and initiated through contacts of the National Research School in General Practice. The study plan for the stay included work on the SWE-diadep study tutored by researchers with high competence in the field, and work on ongoing studies at the George Institute for Global Health. The 'pre-doc' stay resulted in paper II, an international collaboration with the researches of the INTERACT2 study, tutored mainly by associate professor Hisatomi Arima and Professor John Chalmers, and paper IV, co-authored by Professor John Chalmers.

\section{ELSA85}

The ELSA85 study (paper I) is a population-based survey where all residents born in 1922 ( $n=650)$ and living in the municipality of Linköping, Sweden, were identified through the local authorities register and invited by letter to join the study at the age of 85 years. Baseline data collection was performed between March 2007 and June 2009 (Figure 2). The data included a postal questionnaire, house call from an occupational therapist and a visit to the geriatric clinic for cognitive testing, blood samples, electrocardiogram (ECG) and physical examination by a doctor. A follow-up was carried out after one year and after five years at 90 years of age.

The postal questionnaire contained questions about medical history and current use of prescribed drugs. It also included the European Quality of Life 5 Dimensions questionnaire (EQ-5D). Medical history was apart from the 
postal questionnaire also obtained from medical records and during the medical examination by use of a specified protocol.

\section{$E Q-5 D$}

The EQ-5D questionnaire is a generic instrument that assesses health-related quality of life (HRQoL) in terms of mobility, self-care, usual activities, pain/discomfort and anxiety/depression[134]. Each dimension has three levels of severity graded from one to three; no problems, moderate problems or severe problems. The EQ-5D also contains a visual analogue scale (VAS) that records the individual's self-rated evaluation of health, ranging from 0 , worst imaginable health status, to 100, best imaginable health status. The scores of the five EQ-5D dimensions (VAS excluded) were converted to a single summary index value generated by means of the time trade off method[135, 136].

\section{Blood pressure}

Blood pressure was measured in a lying position after 5 minutes rest. Hypertension was defined as a SBP $>140 \mathrm{~mm} \mathrm{Hg}$ or diastolic blood pressure (DBP) $>90$ or ongoing antihypertensive medication in accordance with World health organization (WHO) guidelines[137].

\section{Body mass index}

Height, waist circumference (to the nearest $\mathrm{cm}$ ) and weight (to the nearest 0.1 $\mathrm{kg}$ ) were measured with the participants wearing light indoor clothing. BMI was calculated using the formula weight $\mathrm{x}$ height $^{-2}$ and defined as underweight if $<18.5 \mathrm{~kg} \mathrm{~m}^{-2}$, normal range 18.5-24.9, overweight 25.0-29.9 and obesity if $\geq 30.0$, according to WHO criteria[138].

\section{Laboratory measurements}

Non-fasting venous blood samples were drawn for measurements of haemoglobin $(\mathrm{Hb})$, plasma glucose, serum creatinine, thyroid stimulating hormone (TSH), C-reactive protein (CRP) and N-terminal of the prohormone 
brain natriuretic peptide (NT-proBNP). NT-proBNP was analyzed using the Elecsys 2010, Roche's method until September 2007 (total imprecision CV at level 180; 6.2\% and at level 1900; 4.8\%), and after that with the Modular E, modified Roche's method (total imprecision CV at level 90; 4.6\% and at level $800 ; 4.5 \%$ ). An eGFR as a parameter of renal function was calculated from serum creatinine level, age and weight according to the Cockroft-Gault formula[139]. An eGFR $\geq 60 \mathrm{ml} / \mathrm{min}$ was classified as normal or mildly impaired renal function, $<60 \mathrm{ml} / \mathrm{min}$ was classified as moderate renal impairment and $<30 \mathrm{ml} / \mathrm{min}$ as severe renal impairment [43].

\section{ECG}

A standard 12 lead ECG was recorded at $50 \mathrm{~mm} / \mathrm{s}$ and $10 \mathrm{~mm} / \mathrm{mV}$ standardization using a MAC 38 PC and interpreted according to American Heart Association's (AHA) guidelines[140, 141] manually and unidentified, by one physician. The review comprised rhythm and pace; sinus rhythm, pacemaker or atrial fibrillation/flutter, bradycardia $(<50$ beats $/ \mathrm{min})$, tachycardia ( $>100$ beats/min), and presence of pathological Q-wave indicating past ischemic event. ECGs were also analyzed according to Cornell voltageduration product, $(\mathrm{RaVL}+\mathrm{SV} 3)$ times duration of QRS complex, adjusted for female gender by adding 6 or $8 \mathrm{~mm}$ to the sum of (RaVL+SV3), with a partition value of $2440 \mathrm{~mm} \times \mathrm{ms}$ to recognize left ventricular hypertrophy (LVH) [142, 143], and complemented with Sokolw-Lyon voltage index (SV1+RV5 or V6) with $>35 \mathrm{~mm}$ as partition value[144].

\section{$\mathrm{CHADS}_{2}$ score and $\mathrm{CHA}_{2} \mathrm{DS}_{2}-\mathrm{VASc}$ score}

Cardio embolic stroke risk was estimated using $\mathrm{CHADS}_{2}$ score (Congestive heart failure, Hypertension, Age $\geq 75$, Diabetes, each 1 point. Prior Stroke or transient ischemic attack[TIA], 2 points). $\mathrm{CHADS}_{2}$ score was calculated in the AF group and two or more points were considered as indication for OAC [145, 146].

The further developed $\mathrm{CHA}_{2} \mathrm{DS}_{2}-\mathrm{VASc}$ risk score is superior for stroke prediction to the $\mathrm{CHADS}_{2}$ score because a lesser proportion of patients are classified as intermediate risk for stroke[147]. $\mathrm{CHA}_{2} \mathrm{DS}_{2}-\mathrm{VASc}$ was used for supplementary analyses (Congestive heart disease 1 point, Hypertension 1 point, Age $\geq 75$ years 2 points, Diabetes 1 point, previous Stroke or TIA 2 
points, Vascular disease 1 point, Age 65-74 years 1 point, female Sex 1 point) [147]. OAC was indicated at a moderate stroke risk; a CHA2 $\mathrm{DS}_{2}-\mathrm{VASc}$ score of $\geq 1$. (A score of $\geq 2$ was considered a high risk of stroke[147]). Data concerning $\mathrm{DM}$, prior stroke or TIA were obtained from the postal questionnaire, medical history provided by study participants during the medical examination and in case of uncertainty by medical records.

\section{Fall risk}

Fall risk was estimated with use of the Downton Fall Risk Index that consider earlier falls, medication, sensory loss, cognitive impairment and walking ability. Three or more points indicate high risk of falling[148].

\section{Cognitive impairment}

Cognitive impairment was evaluated with a Mini Mental State Examination (MMSE) where 26 points of 30 or less were considered as mild cognitive impairment and 20 points or less as moderate to severe cognitive impairment[149]. 


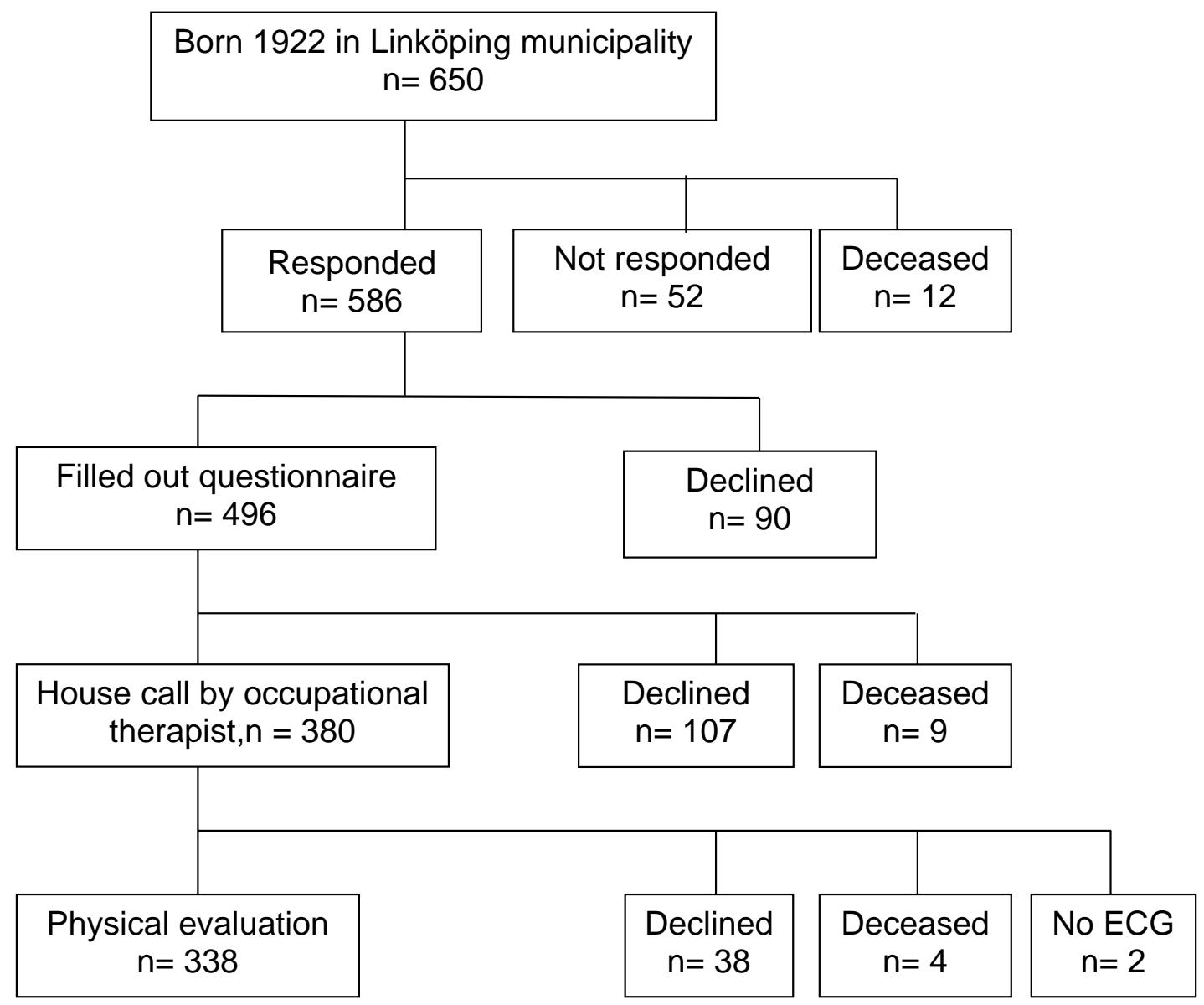

Figure 2. Participant flowchart, baseline evaluation of ELSA85, 2007-2009 (paper I) 


\section{INTERACT2}

The INTERACT2 (paper II) is an international, multicentre, randomised controlled trial by The George Institute for Global Health comparing early intensive (target SBP of $<140 \mathrm{mmHg}$ within 1 hour of randomisation) with guideline-recommended (target SBP $<180 \mathrm{mmHg}$ ) blood pressure control in 2839 adult patients with spontaneous ICH within 6 hours and elevated SBP (150-220mmHg) from 144 hospitals in 21 countries during 2008-2012.

Demographic, clinical features including blood pressure, non-fasting venous blood samples and medical history, including current treatment for CVD, were recorded at inclusion. Patients were excluded if they had a definite indication for, or contraindication to, intensive blood pressure lowering treatment, a structural cerebral cause for the ICH, deep coma (scores 3-5 on the Glasgow Coma Scale) or massive haematoma with a poor prognosis, or if early surgery was planned to evacuate the haematoma. The diagnosis of ICH was confirmed with computed tomography (CT) or magnetic resonance imaging. Participants were followed up in person or by telephone at 28 days and at 90 days by trained local staff. Participants who did not receive the assigned treatment or who did not adhere to the protocol were followed up in full.

\section{NIHSS}

Stroke severity was assessed by use of the National Institutes of Health Stroke Scale (NIHSS), scores range from 0 to 42 , with higher scores indicating a more severe neurologic deficit[150].

\section{mRS}

The Rankin Scale slightly modified by Warlow to the modified Rankin Scale (mRS) evaluates the overall independence of stroke patients and refers to previous activities, thus rending information on lifestyle restrictions due to the stroke. It also allows comparison between patients with different kinds of neurologic deficits[151]. The mRS scores range from 0 (no symptoms) to 6 (death). The primary outcome measure was a poor outcome; death or major disability (defined as a score of 3 to 6 on the mRS[152]) at 90 days postrandomisation. The key secondary outcome was physical function across all seven levels of the mRS. 


\section{$E Q-5 D$}

HRQoL was assessed with the EQ-5D questionnaire[134, 135]. EQ-5D scores were dichotomised to 'any problems' vs 'no problems'.

\section{SHADES}

The SHADES study (paper III) is a prospective cohort study over 30 months, exploring mortality, morbidity, and use of pharmaceuticals in people living in nursing homes in Sweden. Data collection took part in three municipalities in southern Sweden: Jönköping, Linköping, and Eslöv $(n=430)$. All participants in the SHADES study were elderly with multiple comorbidities, living in nursing homes with a mean age of $85(58-101)$ years. Exclusion criteria were severe illness, palliative care or severe language problems. The baseline comprehensive assessment was performed between March 2008 and September 2008 and the participants were then evaluated every 6 months for the rest of the study period, at most six times. The data collection was completed in April 2011.

Two individuals were excluded in the dataset of this study to fit the age span of age 65 years or older and 22 individuals were excluded due to missing data on blood pressure measurement at baseline, thus 406 participants were eligible for further analyses (Figure 3). Data comprised fasting venous blood samples and a medical examination performed every six months by trained local nurses. Medications were classified by the Anatomic Therapeutic Chemical system (ATC) and diagnoses classified according to the International Classification of Diseases, 10th version (ICD-10).

\section{Laboratory measurements}

Fasting venous blood samples were analysed for plasma creatinine, plasma cystatin $\mathrm{C}, \mathrm{TSH}, \mathrm{Hb}$, plasma brain natriuretic peptide (BNP) and p-glucose levels. The eGFR was calculated from the cystatin $C$ value using the Grubb formula[153]. An eGFR $\geq 60 \mathrm{ml} / \mathrm{min} / 1.73 \mathrm{~m}^{2}$ was classified as normal or mildly impaired renal function, $<60 \mathrm{ml} / \mathrm{min} / 1.73 \mathrm{~m}^{2}$ was classified as moderate renal impairment and $<30 \mathrm{ml} / \mathrm{min} / 1.73 \mathrm{~m}^{2}$ as severe renal impairment[43]. 


\section{Blood pressure}

Blood pressure was measured three times with an aneroid sphygmomanometer in a sitting position and comfortably resting for 5 minutes before the measurement. Participants were categorized into four groups according to their SBP: $<120 \mathrm{mmHg}, 120-139 \mathrm{mmHg}, 140-159 \mathrm{mmHg}$ or $\geq 160 \mathrm{mmHg}$. Orthostatic blood pressure was measured after standing for 1 minute and an orthostatic reaction was present if there was a decrease in SBP of $\geq 20 \mathrm{mmHg}$ or a decrease in DBP of $\geq 10 \mathrm{mmHg}[154]$.

\section{The Mini Nutritional Assessment}

The Mini Nutritional Assessment (MNA) screening tool was used to evaluate nutritional status and the presence or risk of malnutrition. The initial sum was calculated and participants with 11 points or less were evaluated in MNA part two. All participants were classified as no risk of malnutrition, risk of malnutrition or present malnutrition[155]. For statistical analyses MNA classification was dichotomised to 'no risk of malnutrition' or 'present or risk of malnutrition'.

\section{Antihypertensive treatment}

Hypertensive treatment was categorized in four groups:

- Diuretics (loop, thiazide or aldosterone antagonists including pyrazine carbonyl guanidine derivatives)

- ACI inhibitors/AII blockers

- Beta-blockers

- Calcium blockers.

Medications were summarized to describe the total use of anti-hypertensive drugs. Fixed combination drugs were categorised accordingly in the different medication categories, respectively. 


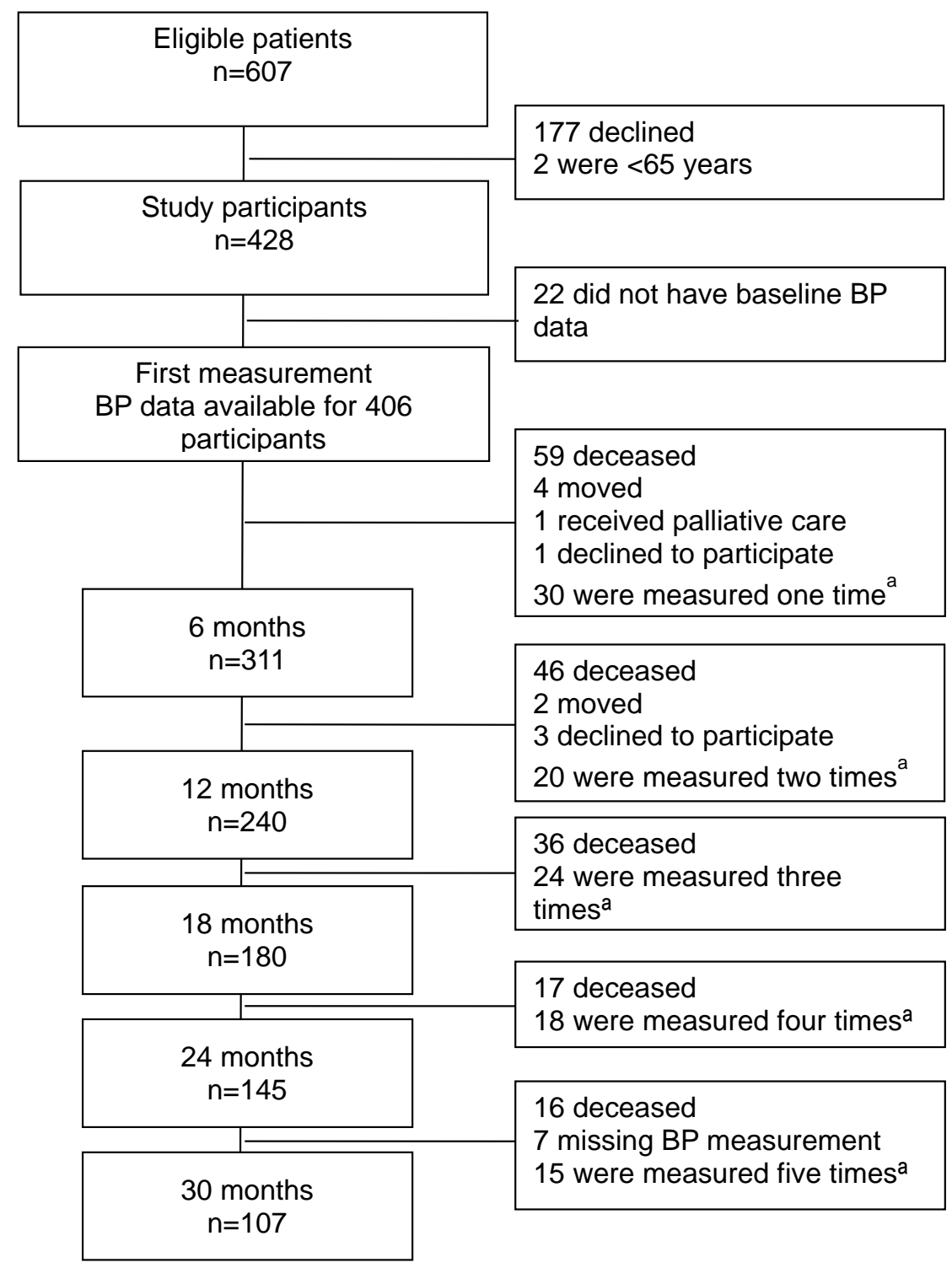

Figure 3. Flowchart of participants in the SHADES study. BP, blood pressure. anclusion was continuous throughout the study period, 20082011 (paper III). 


\section{SWE-diadep}

The SWE-diadep study (paper IV) is a prospective, longitudinal register study of all Swedish residents, 45-84 years old, $n=4083719$, exploring dispensed antidiabetics, antidepressants and first MI at an individual-level, through the use of nationwide registers.

\section{Registers}

Data from three different national registers were combined to render a database on all Swedish residents, ages 45-84 years. From these registers dates, unique personal identification number, diagnosis according to the ICD-10, dispensed pharmaceuticals according to the ATC classification system and data on first fatal or non-fatal MI were obtained. Study participants that suffered a re-infarction during the study period, 2005-2010, were excluded.

- The Swedish Prescribed Drug Register (National Board of Health and Welfare)[156]

- The Myocardial Infarction Statistics (National Board of Health and Welfare)[157]. This register was based on information from the Cause of Death Register (National Board of Health and Welfare) and the National Patient Register (National Board of Health and Welfare).

- The Total Population Register was used to render a complete database on all Swedish residents in the age span and with no re-infarction during 2005-2010. The participants obtained from the individuallevelled registers for antidiabetic and antidepressant treatment and diagnosis for MI were subtracted from the total number of individuals acquired from the Total Population Register (Statistics Sweden)[3].

The Myocardial Infarction Statistics register holds information on MI diagnosis from all secondary care units dating back to 1987, which enabled inclusion of participants with a first MI only. The Swedish Prescribed Drug Register holds information on all dispensed pharmaceuticals, both from public and private prescribing physicians. 


\section{Dispensed drugs as markers of disease}

Dispensed antidiabetics (ATC A10), antidepressants (ATC N06A) and antihypertensive drugs (ATC C03 and C07-09) were used as markers of disease. All participants were categorised according to dispensed antidepressants and/or antidiabetics. The cohort was followed for three years, from January 2008 to December 2010. There was a run in period for two years (January 2006 to December 2007) and participants were classified in four treatment categories:

1) Antidiabetic and antidepressant treatment combined.

2) Antidepressant treatment only.

3) Antidiabetic treatment only.

4) Neither antidiabetic nor antidepressant treatment.

Antihypertensive drugs were used for adjustment.

\section{Categorisation}

Participants were reallocated to one of these treatment groups in 2009 and 2010. The classification was based on dispensing of antidiabetic and/or antidepressant drugs on at least one occasion during the previous two years. Once categorised as 'antidiabetic \& no antidepressant' or 'antidepressant \& no antidiabetic', participants could not be classified as 'no antidiabetic \& no antidepressant', but could shift unidirectional from having 'antidiabetic \& no antidepressant' or 'antidepressant \& no antidiabetic' to 'antidiabetic \& antidepressant' the following year if both antidiabetics and antidepressants were dispensed (Figure 4). 


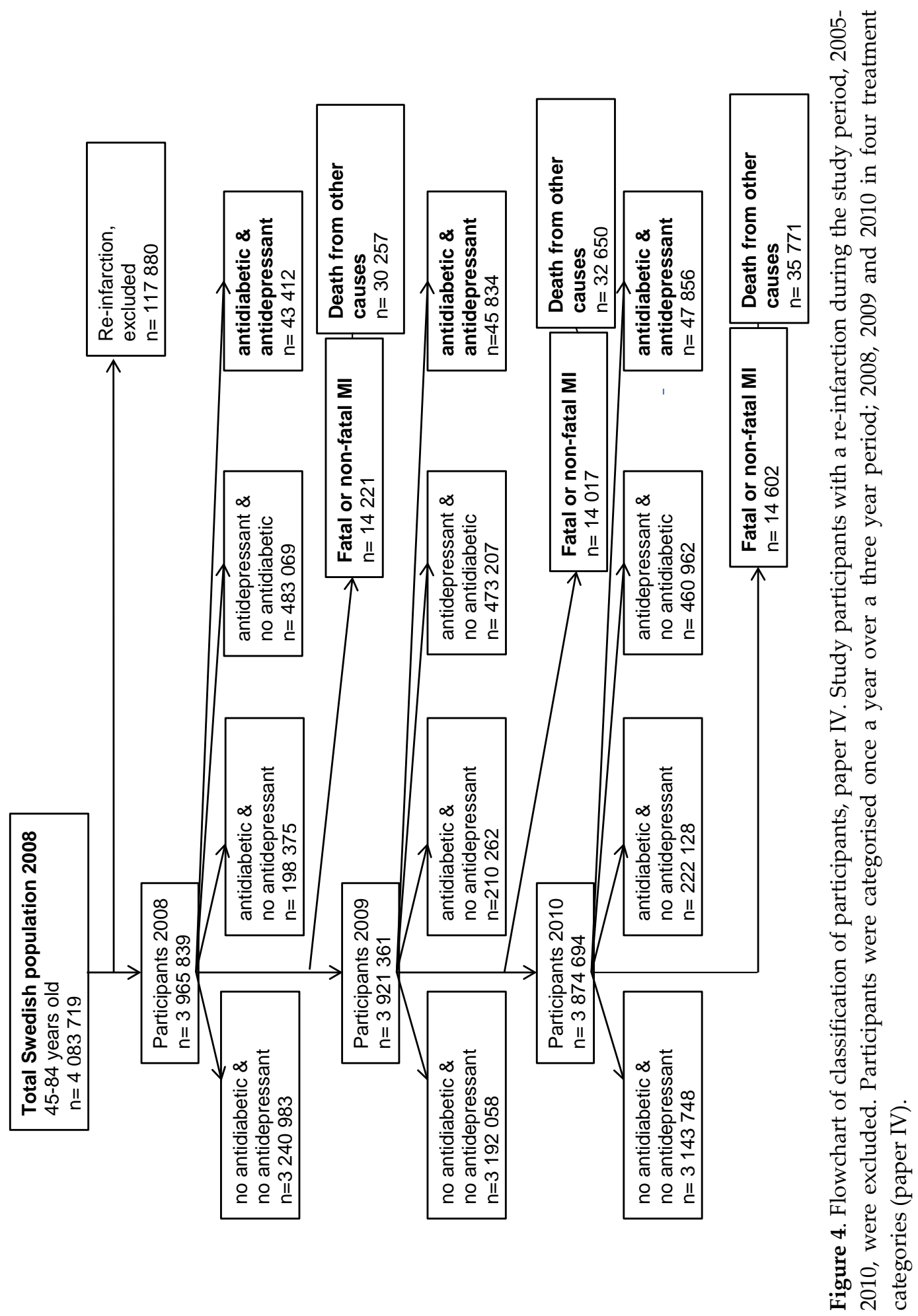




\section{Statistical analyses}

SPSS Statistics 18-22 were used for analysis in all studies, SAS software version 9.3 and the STATA software version 13.0 were used in the INTERAC2 trial and $\mathrm{R}$ - 3.2.0 were used in the SWE-diadep study. Statistical significance was set at a $\mathrm{p}$-value $<0.05$, two sided. Continuous variables with normal distribution were presented with mean and standard deviation (SD). If the variable was not normally distributed (tested with the Kolmogorov-Smirnov test) median and interquartile range (IQR) was used. For categorical variables count and percentages were used for description. Differences in categorical variables were analysed with Pearson's chi-squared test (paper I and III). (Categorical variables with cells that had an expected count less than five was analysed with the Fisher exact test). Continuous variables were examined with Student's $t$-test or the Kruskal-Wallis test if not normally distributed (paper III) or the Mann-Whitney U test (paper I). A statistician was consulted in papers I-III and calculations for paper IV were done in collaboration with a statistician due to the large sample size that required statistical expertise.

\section{ELSA85}

Supplementary calculations for AF based on ECG at inclusion together with history of AF were made. Supplementary logistic regression analyses, both univariate and multiple were performed with 'AF at inclusion' as dependent variable (model $1, \mathrm{AF} \mathrm{n}=53$ ) or ' $\mathrm{AF}$ at inclusion together with history of $\mathrm{AF}^{\prime}$ (model 2, AF $\mathrm{n}=71$ ). Variables with a $\mathrm{p}$-value $<0.1$ were included in the multiple logistic regression models. Results were reported as odds ratios (OR) with associated $95 \%$ confidence intervals (CI).

All-cause mortality in the AF and non AF groups after five years was analysed with a Cox regression analysis. Variables with a p-value $<0.1$ in the baseline multiple analysis (model 1, $\mathrm{n}=53$ ) were included in the survival analysis. The results were shown as hazard ratios (HR) together with 95\% CI. 


\section{INTERACT2}

Participants in the INTERACT2 trial were divided into five (quintiles) age groups. Differences in baseline characteristics between age groups were assessed using a simple linear regression model. Associations between age category and primary outcome (death or dependency; mRS score 3-6), and secondary outcomes; death, dependency alone and HRQoL (EQ-5D scores dichotomised to 'any problems' vs 'no problems') were analysed with logistic regression, and reported as an OR with associated 95\%CI. An ordinal regression was used to evaluate the key secondary outcome (physical function across seven levels of the mRS)[158]. Associations between age in quintiles and study outcomes were analysed in multiple logistic regression models.

\section{SHADES}

A Cox regression analysis was used in the SHADES study to estimate relationships between SBP at inclusion and time to death adjusted for age and sex. All remaining participants were censured at the end of the follow-up period (April 2011). Four SBP categories were included in the Cox regression model and SBP 120-139 mmHg was used as the reference group. Age was measured as a continuous variable. Changes in SBP over time in a subgroup of 180 participants were compared on an individual level using a paired Student's t-test.

\section{SWE-diadep}

In the SWE-diadep study, a Cox regression analysis was performed using the time from January 2008 to first fatal or non-fatal MI event as the follow-up time variable. Participants with no MI event were censured at the time of death or the end of the follow-up period, December 2010. Treatment category was used as time dependent variable. HR estimates with 95\%CIs were calculated for the three categories with antidiabetics and/or antidepressants (category 1, 2 and 3) compared to the reference group with no antidiabetics or antidepressants (category 4). Participants were stratified by gender and age group (45-64 years and 65-84 years). A supplementary Cox regression analysis was carried out for the oldest participants, aged $80-84$ years. 


\section{Ethical considerations}

All studies complied with the Declaration of Helsinki. Written informed consent was obtained from each participant or legal surrogate. For the INTERACT2 trial this was done in accordance with national regulations at each participating site. The studies resulting in papers I, III and IV, were approved by the Regional Ethical Review Board at Linköping University, Sweden (Dnr 141-06, 150-07 and 2011/489-31). All participants could withdraw at any point if they chose to. Also, those approved for participation by the next of kin, who could not understand or were not able to consent due to medical issues could withdraw at a later stage. Participants suffering from dementia were not physically examined or put through blood sampling if they resisted at the time for evaluation. All data were unidentified, presented on a group level and specific individuals could not be singled out and identified. The risk for harm was over all considered low and the gain of new knowledge valuable which motivated performing the studies. 


\section{RESULTS AND COMMENTS}

\section{ELSA85}

\section{Atrial fibrillation (AF) and co-morbidity in elderly. A population based survey of 85 years old subjects.}

\section{Results}

Out of the 336 participants 53 had an ECG showing AF which comprised 16\% of the study population. There were few observed differences between the AF and non-AF groups. 18 participants in the 'sinus rhythm or pacemaker' group had a history of AF. Out of these 15 had an AF diagnosis of which two had pacemaker. In table 1, supplementary columns have been added to show both cross sectional results based on ECG at inclusion (paper I) and history of AF and/or present AF (all variables with differences between 'AF cross section at baseline' and 'AF cross section at baseline together with history of $\mathrm{AF}^{\prime}$ are shown). This did not change the main results. 


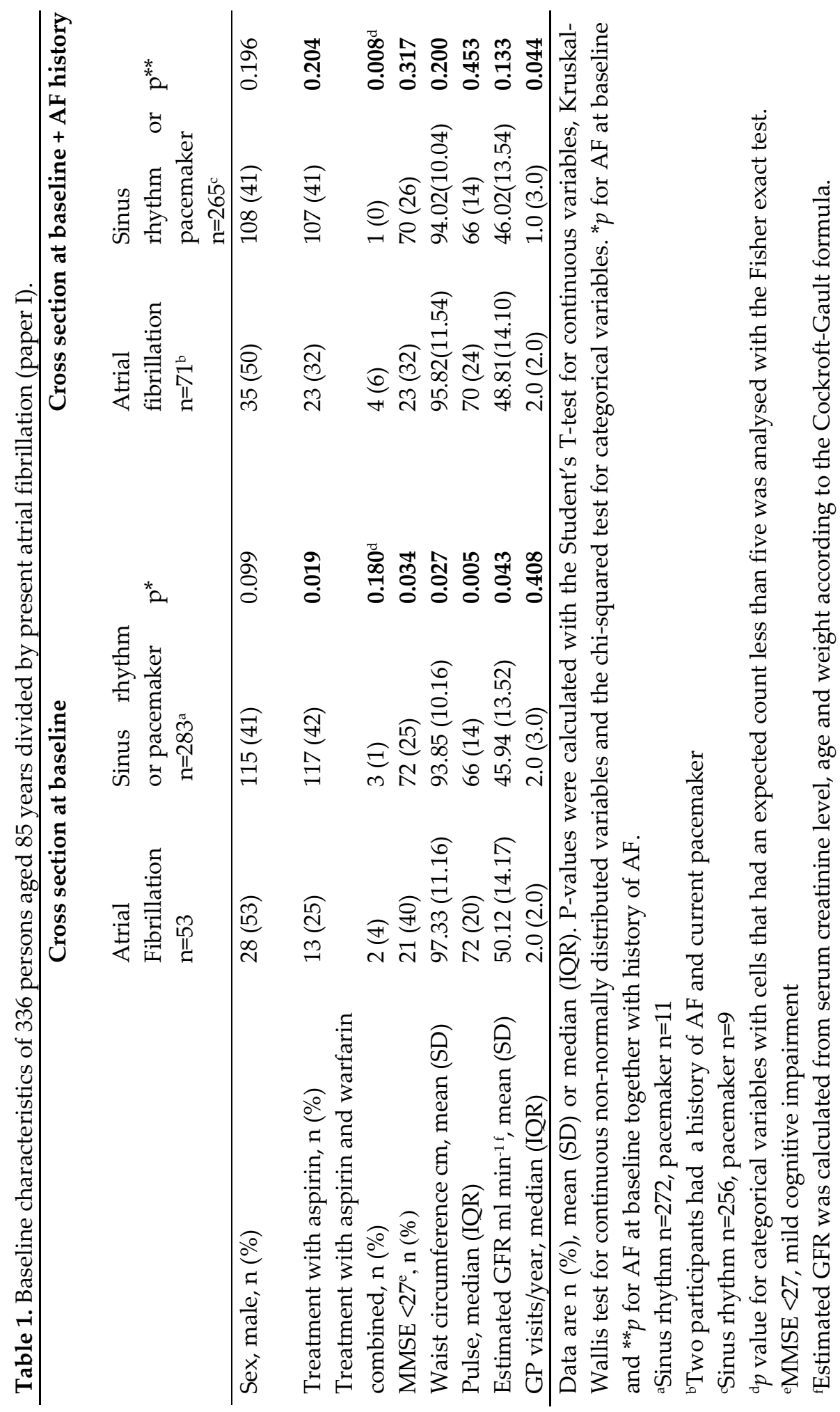


A supplementary univariate logistic regression analysis did not change the observed differences between the AF and the non AF groups. There were also virtually no differences when AF at baseline and history of AF $(n=71)$ was entered as dependent variable instead of ECG showing AF at baseline $(n=53)$. In the multiple model 1 analysis significant differences persisted at large, except for SBP $(p=0.333)$, total number of admitted days/year $(p=0.090)$ and treatment with aspirin $(\mathrm{p}=0.392)$, beta blockers $(\mathrm{p}=0.731)$ and ACE inhibitors/AII blockers $(\mathrm{p}=0.992)$. In the second multiple analysis, model 2, significant differences also persisted, except for CHF ( $\mathrm{p}=0.125), \mathrm{BMI} \geq 30 \mathrm{~kg} / \mathrm{m}^{2}$ $(\mathrm{p}=0.088)$, SBP $(\mathrm{p}=0.071)$, treatment with aspirin $(\mathrm{p}=0.565)$ or ACE inhibitors/AII blockers $(\mathrm{p}=0.599)$.

19 of 53 participants with AF (36\%) did not have OAC treatment. Their medical records showed that six had a noted contraindication for OAC. In one case due to severe ICH following warfarin treatment and in five cases due to increased fall risk and dementia. Four patients with a noted contraindication to OAC had prophylactic treatment with ASA instead, ranging from 75 to 320 $\mathrm{mg}$. There was no noted contraindication in five cases. One person did not have AF diagnosis. In this case the ECG was difficult to interpret, the automatic interpretation (not used in the study) also showed an 'indeterminable rhythm'. One participant was misclassified as not on OAC treatment, this participant had warfarin treatment. Two participants were recommended, but chose not to take OAC treatment. (Out of the 19 participants without OAC treatment, four were given treatment after the baseline evaluation was finished).

In the follow-up evaluation at 90 years 113 persons participated. Out of these $16(14 \%)$ had AF at the baseline ECG evaluation. 128 of 336 participants had died (38\%). A survival analysis showed an increased HR for all-cause mortality in participants with AF at baseline (HR 1.61, 95\% CI 1.05-2.45, $\mathrm{p}=0.029$ ) adjusted for sex. This increase in HR did not persist when further adjusted for CHF only, and consequently also not when adjusted for all variables with a p-value $<0.1$ at baseline $\left(\mathrm{SBP}, \mathrm{CHF}, \mathrm{BMI} \geq 30 \mathrm{~kg} / \mathrm{m}^{2}, \mathrm{NT}\right.$ proBNP, warfarin treatment, estimated GFR $<30 \mathrm{ml}^{-1}$, prevalent tachycardia and total number of admitted days/year). In fact, the only significant difference was gender, men had an increased HR for all-cause mortality of 1.65 (95\%CI 1.13-2.40, $\mathrm{p}=0.009$ ). 


\section{Comments}

This study showed that the investigated population of 85 year old persons with atrial fibrillation was surprisingly healthy in terms of healthcare contacts and overall HRQoL. AF at baseline did not increase the risk for all-cause mortality at 90 years of age.

In the AF group, there was an indication for stroke prevention with $\mathrm{OAC}$ treatment in most cases estimated with both the $\mathrm{CHADS}_{2}$ and the $\mathrm{CHA}_{2} \mathrm{DS}_{2}-$ VASc risk scores. When the latter was used, there was an OAC indication for all participants with AF.

\section{INTERACT2}

\section{Older age is a strong predictor for poor outcome in intracerebral haemorrhage: the INTERACT2 study}

\section{Results}

NIHSS scores progressively increased with increasing age categories. Lobar location and presence of intraventricular extension were also more common in the categories of older age. Current use of antihypertensives was significantly less frequent in the categories of younger age but there was no association of age with history of ICH or hypertension. 81 patients (3\%) received treatment with warfarin at ICH onset, $45(56 \%)$ of these individuals were in the oldest age quintile, $>75$ years.

Figure 5 shows that increasing age was associated with increasing frequency of death or dependency (multiple adjusted OR 4.36, 95\% CI 3.12-6.08 for $>75$ years vs $<52$ years, $\mathrm{p}$ for trend $<0.001$ ). Worse HRQoL, including problems with mobility, self-care, usual activities, depression (all p for trend $<0.001$ ), and pain or discomfort ( $\mathrm{p}$ for trend 0.022 ) were more common in participants $>75$ years compared to $<52$ years. The association between age and death or dependency remained significant even after further adjustment for admission to an intensive care unit and for withdrawal from active care $(p<0.001$ for trend). The key secondary outcome, physical function across seven levels of the mRS, worsened across increasing age categories ( $p$ for value trend $<0.001$ ), 
with those over 75 years of age having a greater than 5 fold odds of worse physical function, or death) OR 5.52 (CI 4.31-7.06).

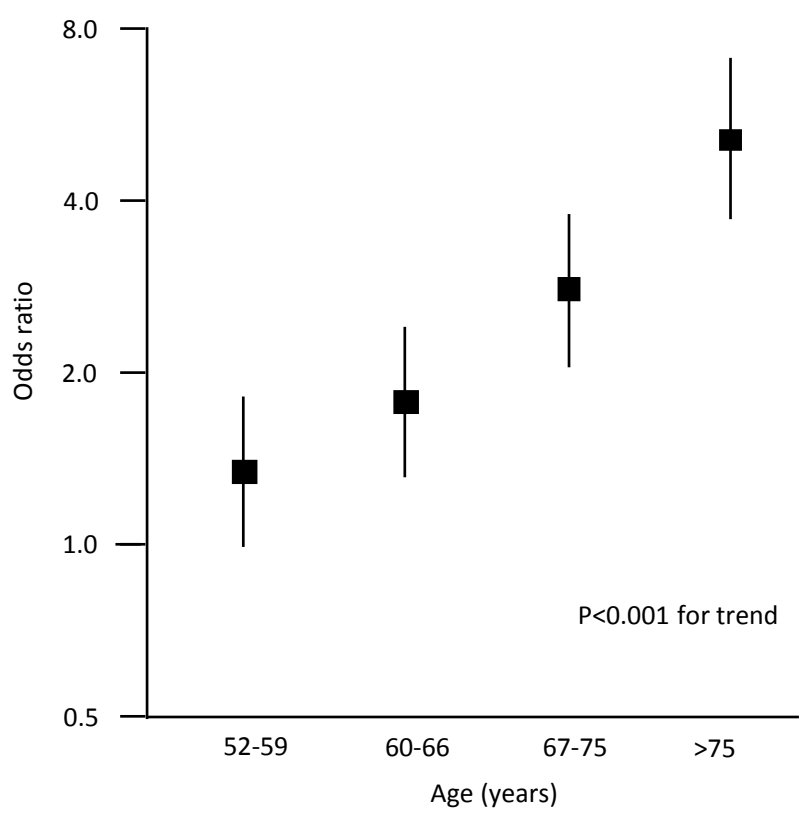

Figure 5. Association of age and primary outcome of death or dependency (mRS 3-6) at 90 days after intracerebral haemorrhage (ICH). Solid boxes represent estimates of odds ratios (OR). Vertical lines represent $95 \%$ CI. Age group $<52$ years was used as reference group. OR were adjusted for sex, recruitment from China, National Institutes of Health Stroke Scale (NHISS) score $\geq 14$, time from onset of ICH to baseline $\mathrm{CT}$, haematoma volume, lobar location of haematoma, intraventricular extension, current use of antihypertensive drugs, systolic blood pressure, prior ICH, prior ischaemic or undifferentiated stroke, DM, glucose and randomised treatment (paper II). 


\section{Comments}

Although based on a selected clinical trial population, this study has shown an association of ageing with several clinical factors shown to be individually connected to poor outcome, such as stroke severity (defined by high NIHSS score), haematoma characteristics (including intraventricular extension), comorbid CVD, DM or prior antithrombotic therapy. There was a strong association between worse functional outcome, defined by the mRS, and increasing age. Antihypertensive drugs were more commonly used in elderly people, but history of hypertension was equally common across age groups, suggesting that younger hypertensive individuals had less adequate antihypertensive treatment.

\section{SHADES}

\section{Blood pressure and all-cause mortality: a prospective study on nursing home residents}

\section{Results}

Low SBP was associated to increased mortality (Figure 6). Mean blood pressure at baseline was 134/72 (SD 23/12) mmHg. 267 (66\%) participants had antihypertensive treatment (ranging between one and four antihypertensives) and $223(55 \%)$ participants were on low-dose aspirin. Apart from the use of loop diuretics, which was more common in participants with SBP $<120 \mathrm{mmHg}$ than in those with higher SBP; there were no differences in pharmaceutical treatment between the SPB groups. Risk of malnutrition or present malnutrition was most common in participants with SBP $<120 \mathrm{mmHg}$. BNP values were significantly higher in the $\mathrm{SBP}<120 \mathrm{mmHg}$ group compared with the three other SBP groups. There was no difference in number of antihypertensives between SBP groups. The use of loop diuretics was most common in the SBP $<120 \mathrm{mmHg}$ group, as was a CHF diagnosis. 


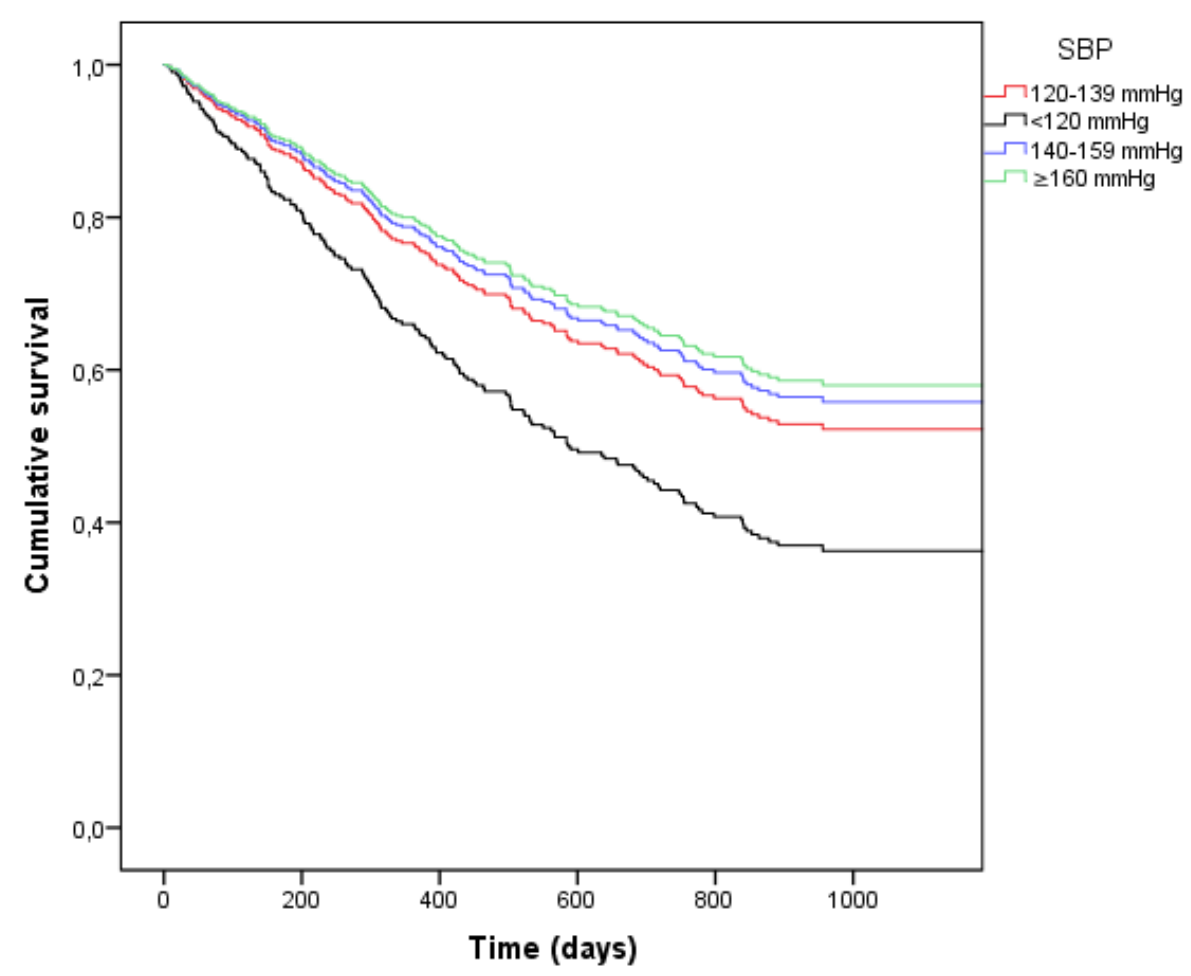

Figure 6 shows survival probability curves for 406 nursing home residents divided by SBP, adjusted for age and sex. SBP $120-139 \mathrm{mmHg}$ was used as the reference category. Participants with SBP $<120 \mathrm{mmHg}$ had an increased HR for mortality (1.56 (95\% CI, 1.08-2.27; $\mathrm{p}=0.019$ ) but there were no differences between SBP groups 140 $159 \mathrm{mmHg}$ and $\geq 160 \mathrm{mmHg}$ compared with the reference group (paper III). 
$174(43 \%)$ participants died during the study. The major cause of death was CVD (including stroke) $\mathrm{n}=77(48 \%)$ cases. Other causes of death were infectious disease, $\mathrm{n}=29(18 \%)$, frailty, $\mathrm{n}=17(11 \%)$ and dementia, $\mathrm{n}=15(9 \%)$. There was no significant difference in the distribution of CVD deaths between blood pressure groups $(\mathrm{p}=0.08)$.

SBP decreased during the prospective study period in a subgroup of 180 participants who were eligible for measurements over 18 months, from a mean of $135 \mathrm{mmHg}$ (SD 22.4) to $130 \mathrm{mmHg}$ (SD 21.0, $p<0.001$ ). This was not associated with changes regarding anti-hypertensive treatment. The participants had a median anti-hypertensive treatment of 1.00 drug (interquartile range, $0.00-2.00, p=0.564$ ) both at baseline and after 18 months (Figure 7). 


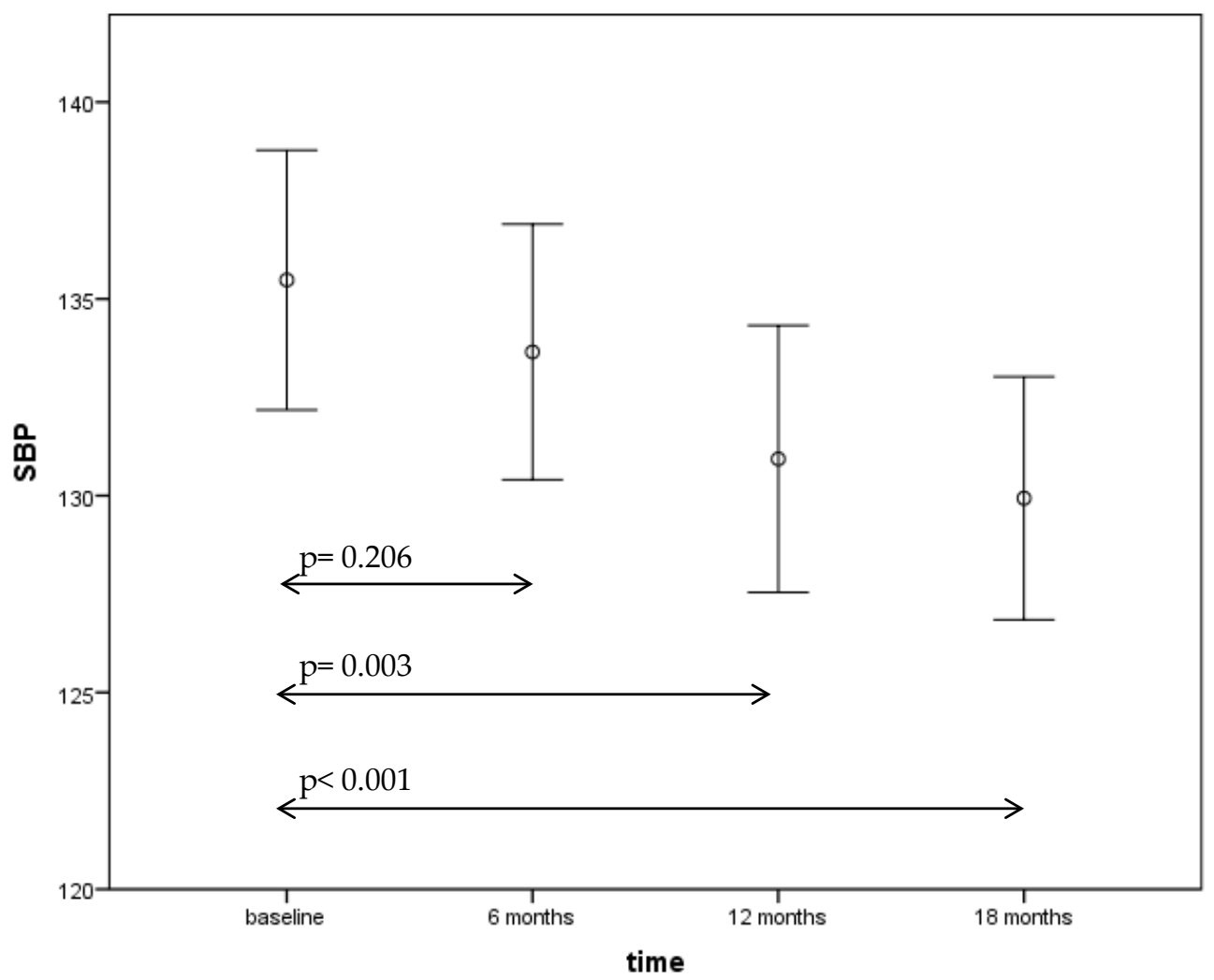

Figure 7. Blood pressure development in nursing home residents over 18 months in a subgroup of 180 participants eligible for measurements (paper III). 


\section{Comments}

Low SBP was associated with increased mortality in elderly individuals living in nursing homes. Also, SBP declined over time, which could not be explained by changes in the use of blood pressure lowering medications. The increased risk for all-cause mortality observed in our study did not change when we adjusted for number of antihypertensives.

\section{SWE-diadep}

\section{The use of antidiabetics and antidepressants is associated to increased risk for myocardial infarction: a nationwide register study}

\section{Results}

In Figure 8, the crude HRs and 95\% CIs for a first MI compared to the reference group i.e. participants without antidiabetics or antidepressants stratified by age and gender are shown. Women with glucose lowering agents and antidepressants in the age category 45-64 years had substantially greater HR for MI (7.4, 95\% CI 6.3-8.6) compared with men (3.1, 95\% CI 2.8-3.6) in the same age category. When the analyses were adjusted for antihypertensive medication the results remained virtually unchanged.

273565 of the 3965839 (6.9\%) participants without re-infarction were 80-84 years old, 114365 (41.8\%) were men and 159200 (58.2\%) women. Of the participating men aged $80-84$ years $11.3 \%$ had antidiabetics, $10.3 \%$ had antidepressants and $2.1 \%$ had antidiabetics and antidepressants combined. The corresponding percentages for women were $7.9 \%, 18.3 \%$ and $2.5 \%$. The MI incidence during follow up in 80-84 years old was 3.4\% $(n=8956)$, where $4.1 \%$ of the men had a first MI and $2.7 \%$ of the women.

The HRs and 95\% CIs for a first MI in participants aged 80-84 years with antidiabetic and antidepressant treatment compared to the reference group of neither antidepressants nor antidiabetics were 1,71 (1.46-2.00) for men and 2.24 (1.96-2.57) for women (Figure 9). 


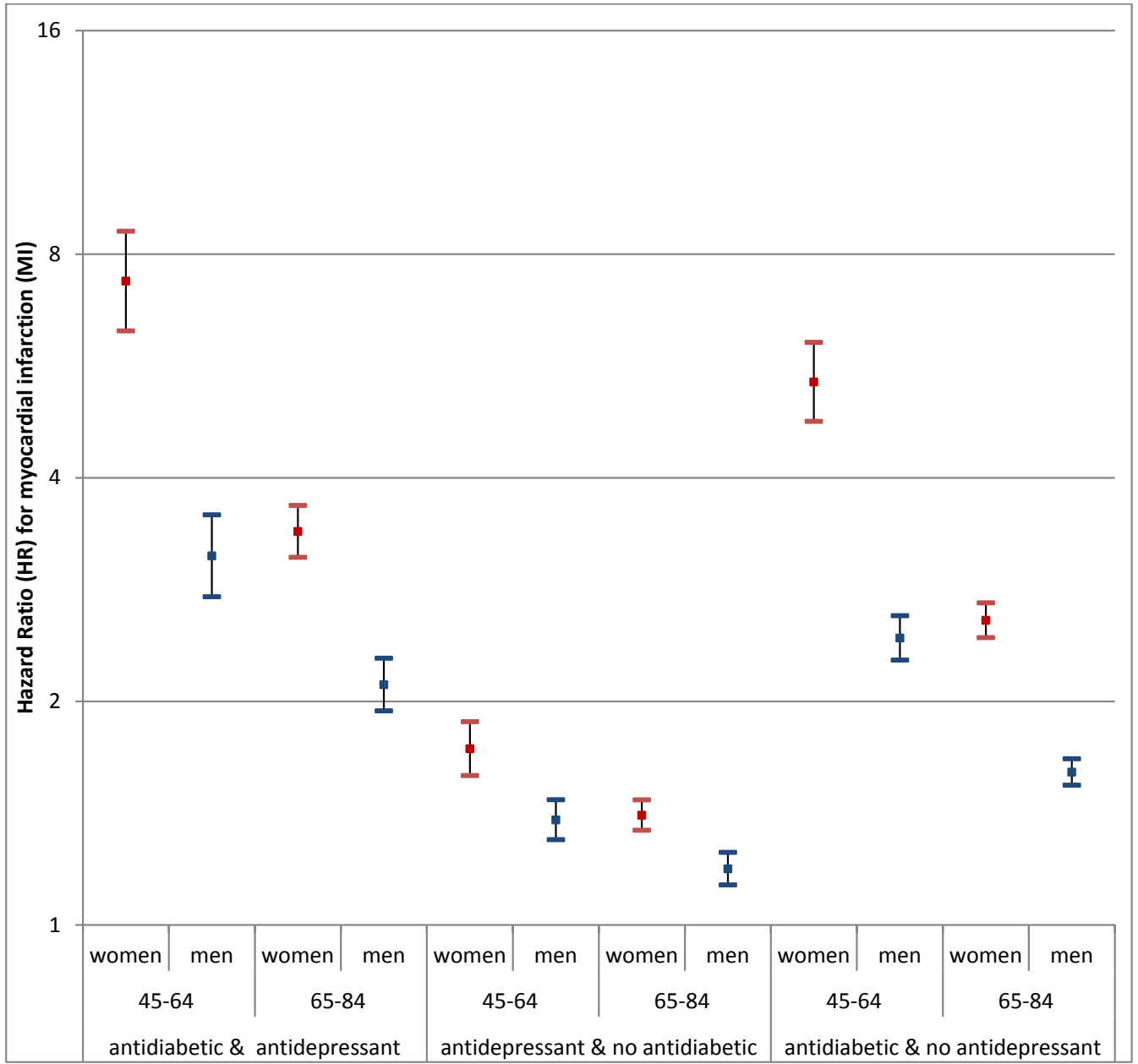

Figure 8. Hazard ratios (HR) for a first myocardial infarction (MI) in participants on treatment with antidiabetics and/or antidepressants in Swedish residents. HR and 95\% confidence intervals (CI) among men (blue) and women (red) with antidiabetics only, antidepressants only, or antidiabetics and antidepressants combined as markers of disease, compared with the reference of neither antidiabetics nor antidepressants. Participants were stratified by age, 45-64 and 65-84 years (paper IV). 


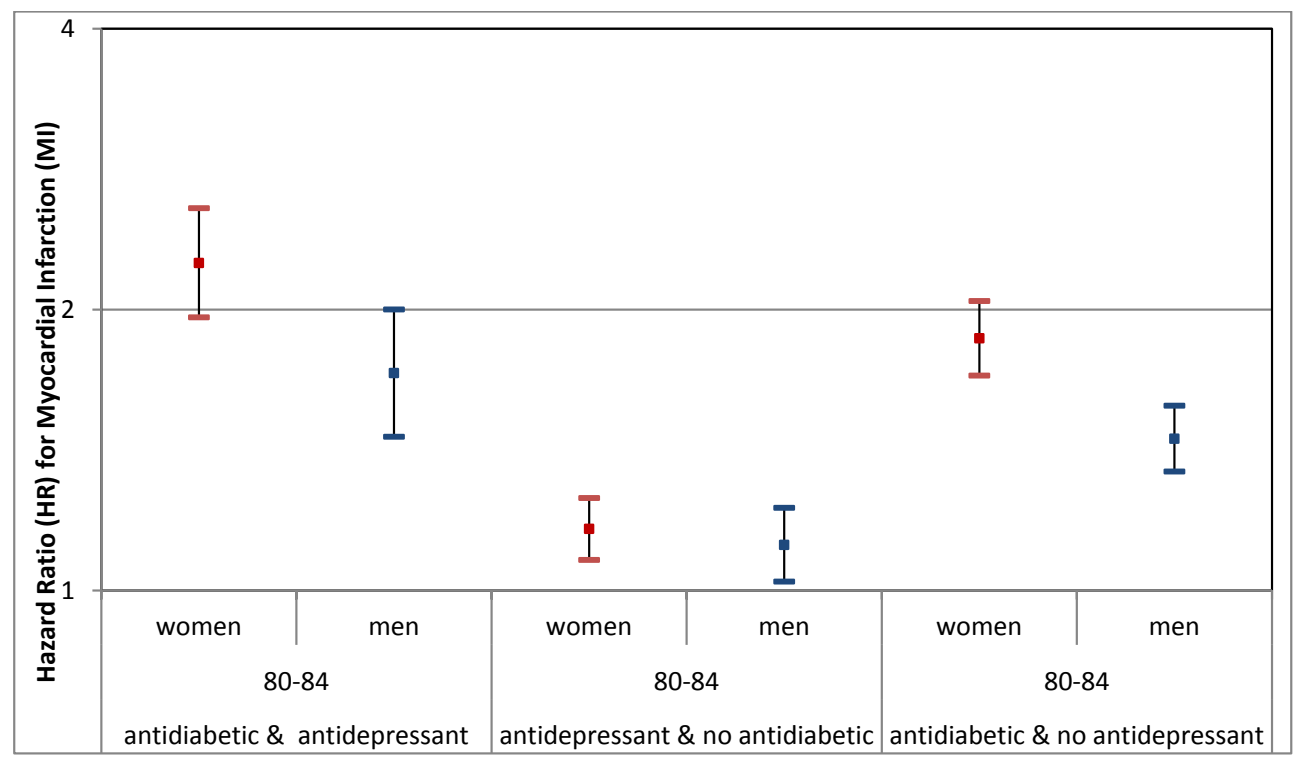

Figure 9. HRs and $95 \%$ CIs for a first $\mathrm{MI}$ in a subgroup of participants aged 80-84 years with antidiabetics and/or antidepressants compared to the reference group of neither antidepressants nor antidiabetics. HR and $95 \%$ confidence intervals among men (blue) and women (red) with antidiabetics only, antidepressants only, or antidiabetics and antidepressants combined as markers of disease compared with the reference neither antidiabetics nor antidepressants. 


\section{Comments}

The combination of antidiabetics and use of antidepressants substantially increased the risk of a first MI compared to categories of none or either of treatments alone. There were gender specific differences. The middle aged women with both antidiabetics and antidepressants had a marked increased HR for a first MI.

In the subgroup of participants aged 80-84 years with antidiabetics and antidepressants combined, there was an increased risk for a first MI as well, but not as markedly as in younger ages. 


\section{DISCUSSION}

The main finding of this thesis is that risk factors for CVD in the oldest old are not as clearly associated to disease and prognosis as in younger adults. The prevalence of AF in the ELSA85 study is high in comparison with some prior studies [159], but corresponds with findings of others[75]. Previously, it has been shown that there are several diseases that are comorbid with AF such as hypertension, CHF, MI, DM and stroke [160]. There were no differences between the $\mathrm{AF}$ and non-AF group for medical history apart from more frequent $\mathrm{CHF}$ in the group with present $\mathrm{AF}$ and elevated levels of NT-proBNP supporting this diagnosis.

Health state scores decreases with age and the EQ-5D index value has been shown to be 0.74 in a general Swedish population aged 80-88 years old[161] which corresponds with the estimated HRQoL in the 85 years old, both with or without AF, in the ELSA85 study. The EQ-5D VAS-scale scores are also in concordance with the Euro heart survey where over 5000 adult patients with AF in all age groups assessed their HRQoL using the EQ-5D VAS scale[162]. Increasing age has been found to be related to worse HRQoL after stroke[163, 164], a finding confirmed in the INTERACT2 cohort. Almost half of those over the age of 75 years had problems with anxiety or depression. Previous studies have shown that older stroke patients are more likely to experience depression, $[165,166]$ even among those who are considered to have recovered fully physically[164].

Increased SBP is generally a risk factor for CVD, dementia and increased mortality[167]. In advanced age, SBP $<120 \mathrm{~mm} \mathrm{Hg}$ has previously been shown to be associated with increased mortality[10, 45, 46, 168], which is in accordance with our results. Previous studies have also shown an association between low SBP and greater prevalence of dementia [47-49], which was not evident in the SHADES study where dementia diagnosis and treatment for dementia were common and not associated with SBP.

A low SBP in older age can be a marker of increasing vascular frailty (a biological process naturally linked to the ageing body) or be associated with a general deterioration in health with age. A large longitudinal study of persons 80 years old or older and living in nursing homes showed that the subgroup 
with low SBP $(<130 \mathrm{mmHg})$ that received two or more antihypertensives had a greater than 2-fold risk for mortality[42]. The increased risk for all-cause mortality in participants with SBP $<120 \mathrm{mmHg}$ observed in the SHADES study did not change when adjusted for number of antihypertensive medications or, two or more antihypertensives.

Due to frailty and mortality it is difficult to perform longitudinal studies of cohorts of very old participants. Because of multiple comorbidities it is difficult to draw conclusions about causality of a finding, such as the association between low SBP and increased mortality in the SHADES study. In the ELSA85 study, there was a loss to follow-up of 223 participants $(66 \%)$ after five years, out of which 119 (35\%) had died. Loss to follow-up was challenging also in the SHADES study, where $174(43 \%)$ participants died during the study. Elderly are not a homogenous group. Some are aged and frail, when others in the same age are healthy and autonomous, which may result in a research bias. In the ELSA85 study all participants were 85 years old. Of the 650 people aged 85 years that received the postal questionnaire, approximately half participated in all parts of the baseline evaluation. Those lost to follow-up (those who did participate to some extent in the baseline evaluation or not at all) did differ significantly from the study participants concerning gender, more women were lost to follow-up than men. They also lived in nursing homes and received home visits from PHC to a greater extent than study participants. There was, however, no significant difference in health service use at the secondary care level[169]. Our results are not generalisable to the entire population of 85 years old, but still valuable for clinical work in the PHC- and geriatric setting.

Adverse drug reactions are observed 2-3 times more frequently in geriatric patients than in middle aged adults[125]. Treatment with diuretics, especially loop diuretics, is one of the major causes of adverse drug reactions and hospital admission in older persons[170]. Furthermore, antihypertensive treatment is associated with increased fall risk and there is evidence that withdrawal of antihypertensive drugs and other medications associated with increased risk of falls can reduce the incidence of falls in elderly[170]. Adverse drug reactions are directly correlated with the number of drugs the patient is taking[38]. Therefore, clinicians should strive to reduce the use of unnecessary drugs in elderly people. It is doubtful whether preventive cardiovascular treatment in severely ill nursing home residents is beneficial for this population. In the SHADES study, $11 \%$ were given statins and $55 \%$ were using 
low-dose aspirin, with no significant differences between the SBP groups. 339 participants (83\%) in the SHADES study and 260 (77\%) in the ELSA85 study took medications affecting the cardiovascular system. In the SHADES study of nursing home residents the total average drug consumption on a daily basis was 6.9 drugs and in the ELSA85 study with a majority of community dwelling participants, it was 5.4.

AF is associated with an increased stroke incidence [90-92] which could not be observed in the ELSA85 study population where there was no difference for prior stroke or TIA between the AF- or non-AF groups. A possible research bias was that elderly in Linköping that had suffered a stroke received nursing home care and chose not to participate in the ELSA85 study. In the INTERACT2 trial there were few OAC treated patients with ICH $(3 \%)$, a possible research bias was that patients with severe $\mathrm{ICH}$ were excluded, and their prevalence of OAC treatment was not known. However, considering the treatment benefits of prophylactic OAC treatment especially in elderly patients with AF[97-99], the risk for ICH as an OAC complication should not be overestimated.

$\mathrm{DM}$ is a substantial risk factor for coronary heart disease, with a further increased risk associated to ageing. We hypothesized that having depression increased the risk for $\mathrm{MI}$ in men and women with $\mathrm{DM}$, to a greater extent than in men and women without DM. Dispensed drugs rather than diagnosis of DM was used as a marker of disease because diagnoses from PHC are not included in the National Patient Register and previous studies have shown that $25 \%$ of the patients with DM are cared for in PHC solely [26]. Misclassification of patients with DM who were receiving dietary treatment only in the non-DM group would underestimate the increased MI risk for the DM population. In addition, oral treatment, mainly with metformin, is generally started early in the course of Type $2 \mathrm{DM}$. We could not show a multiplicative interaction, but there was a marked difference in risk for MI for individuals with both antidiabetics and antidepressants. This is in alignment with previously reported data[171]. In the general population women are at much lower risk for ischemic heart disease mortality than men are. However, it is widely held that women with DM are at especially high risk for coronary heart disease, relatively more so than men with type $2 \mathrm{DM}$, meaning that the impact of DM on the risk of coronary death is significantly greater for women than men[58]. This finding was confirmed in the SWE-diadep study and the 
gender specific relative difference in the risk for first fatal or non-fatal MI was most clear in the middle aged category.

With an increasing number of aged people globally, health care systems have to adapt to the needs of an older population with multimorbidity, chronical illnesses and increased needs of health care and medical treatments. Data on functional outcome after ICH are limited in elderly patients[172]. In the INTERACT2 study of outcomes after ICH, we showed that the older participants had much worse outcomes than young. Even though there was no difference between history of hypertension between young and old ICH patients, old patients with ICH had antihypertensive treatment to a higher extent than young. There was an overall majority of Chinese participants, predominantly in the younger age categories. The Chinese ICH patients with history of hypertension had antihypertensive treatment to a significantly lesser extent compared to the other participating countries (grouped together), which points out the global injustice of health care and treatment availability.

The Swedish PHC commission is regulated by law and includes basic medical needs: treatments, general care, preventive medicine and rehabilitation, all of which when the patient is not in need of secondary care[173]. Limited availability in PHC has been a challenge for many years and improving this has been a political goal for quite some time. Structural changes have been made since 2007, the 'Vårdval i primärvården' (PHC choice) and 'vårdgaranti' (guaranteed care) reforms. However, it is uncertain if these reforms have had positive effects for the oldest population since there has been a focus primarily on availability of PHC and not continuity of care giver[174, 175]. In 2000 a number of national strategic goals were described for the Swedish health care, one of which was care of old people[173]. PHC was to be improved in terms of continuity, availability and quality. The demographic changes with an ageing population combined with the increased need of out-patient care due to shorter stays in hospital, lack of hospital beds, more advanced out-patient medical treatments and other structural changes are increasing challenges for the Swedish PHC[175]. Future elder care must take into account the complexity in the care of frail elderly individuals and structural health care changes are necessary to offer individually adapted care for the oldest old. 


\section{Strengths and limitations}

This thesis is based on four different studies which offer both strengths and limitations. Strengths are the width of the material that enables exploration of different aspects of the research questions and increase the generalisability. Limitations are that the age distribution varies between the different materials, and study planning was not based on findings of previous studies from the thesis.

A limitation of the ELSA85 baseline evaluation is the relatively low number of participants with AF. Furthermore, the cross sectional design precludes conclusions about causality. However, this does not undermine the fact that the participants with AF were found not to differ in major respects compared to the participants without AF.

Strengths of the INTERACT2 study include the large prospective cohort design with very low loss to follow-up. A wide range of patient characteristics and health care settings were involved increasing generalisability. Rigorous evaluation of outcomes helped ensure reliability. However, a major limitation was the exclusion of those patients with poor prognosis, which may have restricted the inclusion of elderly patients with severe $\mathrm{ICH}$.

Strength of the SHADES study was the homogeneity of the study population located in various parts of Sweden, diminishing possible differences due to treatment traditions. Limitations were the high mortality rate and continuous inclusion during the study period that meant that very few participants could be followed for the whole 30 months. From this observational study, it was not possible to draw conclusions about causality between the association of low SBP and mortality. Furthermore, the observed outcome may be due to reverse causation, i.e. pre-existing illness may explain both low blood pressure and impending death.

The strengths of the SWE-diadep study include the large study population, which made it possible to stratify data into subgroups and still have statistical power to achieve valid results. Another strength is that the data were population-based, with complete national coverage which reduces possible recall and selection bias. The different registers used have high validity[176] and full coverage of the requested variables. There were some limitations because of the study methodology. We had no information for the reasons for 
antidepressant and antidiabetic treatment. The indication for treatment may therefore have been a wide range of conditions, such as neuralgias or anxiety disorders. The study design meant that only one dispensing of antidepressant drugs during the study period qualified to categorisation in the antidepressant category and we did not have information regarding any dispensing of antidepressants before the run-in period 2006 - 2007. We also lacked information on important factors such as physical activity habits, smoking status, lipids, BMI and other current medications apart from antihypertensives, such as lipid-lowering agents.

\section{Clinical implications and future research}

There is an abundancy of studies in the cardiovascular research field, of which few address the cardiovascular health of the oldest old. This thesis contributes with clinical aspects to the evidence based knowledge about the treatment of cardiovascular risk factors in old age. There are differences in cardiovascular risks depending on gender. The finding that middle aged woman with antidiabetics and antidepressants combined are at relatively greater risk for MI than middle aged men is important clinically. Women with DM and depressive disorders combined should be given careful attendance. Furthermore, the guideline recommendation of a blood pressure treatment target of $<150 / 90$ in elderly over 80 years (the American Society of Hypertension and the International Society of Hypertension) is questionable in elderly, frail persons. It is important with systematic drug reviews in older persons in nursing homes, paying special attention to those with low SBP. If an ICH has occurred, the finding of worse prognosis with ageing will help guide clinicians in discussion with patients and their families about the likely outcomes in the acute phase of ICH.

Future studies of drug withdrawal could render further knowledge, if aged and ill persons survive longer and with better HRQoL if antihypertensive treatments are reduced. With the new NOAC drugs, future studies should strive to evaluate safety also for aged and frail patients with AF. Also, the homogeneity of the elderly in society needs to be further addressed to ensure good, evidence based health care and adequate preventive measures for all elderly. 


\section{CONCLUSIONS}

\section{General conclusion}

Risk factors for CVDs in elderly differ from cardiovascular risk factors in younger persons and are not as clearly associated to disease and prognosis as in middle aged individuals.

\section{Specific conclusions}

- 85 year old persons with AF, mainly community dwelling, are relatively healthy and do not have impaired HRQoL or more health care contacts than individuals without AF in the same age.

- Old patients with ICH do in comparison with younger ICH patients have worse outcomes in terms of death and disability, and worse HRQoL.

- Nursing home residents have an increased risk for all-cause mortality if the SBP is low $(<120 \mathrm{mmHg})$. The SBP also declines over time in a nursing home cohort.

- Treatment with antidepressants and antidiabetics constitutes a greater risk for a first MI than antidiabetics alone, especially in women 45-64 years old. 


\section{POPULÄRVETENSKAPLIG SAMMANFATTNING}

Den snabbast växande åldersgruppen, både i Sverige och internationellt är individer över 80 år. Detta beror framförallt på socioekonomisk utveckling och medicinska framsteg med minskad spädbarnsdödlighet och minskad dödlighet i infektionssjukdomar. Det beror också på bättre behandling av kroniska sjukdomar. Hjärt-kärlsjukdom, exempelvis hjärtinfarkt och stroke, är den vanligaste dödsorsaken globalt. Förekomsten av kroniska sjukdomar ökar stadigt, främst beroende på att allt fler blir allt äldre. Insjuknande i stroke, diabetes och förmaksflimmer är starkt kopplat till stigande ålder. Flera riskfaktorer för hjärt-kärlsjukdom går att påverka genom levnadsvanor och medicinsk behandling, av vilka högt blodtryck (blodtrycksnivåer över 140/90 $\mathrm{mmHg}$ ) är den viktigaste ur hjärt-kärlsjukdomssynpunkt.

När vi åldras förändras både kroppens signalsystem och fördelningen mellan muskelvävnad, fettvävnad och kroppsvatten. Njurfunktionen försämras och allt detta påverkar sammantaget förmågan att fördela och utsöndra läkemedel. Det gör att äldre inte svarar på samma sätt som yngre på läkemedelsbehandling och det finns en ökad risk för oönskade läkemedelseffekter. Behandling med flera olika läkemedel, vilket är vanligt vid hög ålder ökar också biverkningsrisken. Merparten av alla studier görs på yngre individer. I många fall saknas helt vetenskapligt stöd för på vilket sätt en åldrad människa ska behandlas med läkemedel, och vilka behandlingsresultat som skall eftersträvas.

Syftet med denna avhandling var att studera åldrande och riskfaktorer för hjärt-kärlsjukdom (förmaksflimmer, högt blodtryck och diabetes), kopplat till samsjuklighet och mortalitet.

I ELSA85-studien (delarbete I) visades att 85-åringar i Linköpings kommun med förmaksflimmer var förvånansvärt friska även om de hade många diagnoser. Den upplevda hälsorelaterade livskvaliteten var hög, och det var ingen skillnad jämfört med dem som inte hade förmaksflimmer, och inte heller jämfört med äldre i andra studier, eller förmaksflimmerpatienter i yngre åldrar. 
I INTERACT2-studien (delarbete II), en internationell studie från 21 länder, visades att ålder vid insjuknande i hjärnblödning har stor betydelse för överlevnad, fysisk funktion och hälsorelaterad livskvalitet efter genomgången hjärnblödning. Ju äldre personerna som insjuknade var, desto högre var risken för resttillstånd eller död.

I SHADES-studien (delarbete III) visades att ett övertryck under $120 \mathrm{mmHg}$ kunde kopplas till ökat dödlighet hos personer boende på sjukhem jämfört med blodtrycksgruppen 120-139 mmHg. Höga blodtryck (över $160 \mathrm{mmHg}$ ) kunde inte kopplas till ökad dödlighet i denna studiepopulation med gamla och sjuka individer. Vi visade också att övertrycket sjönk under en 18 månadersperiod.

I SWE-diadep-studien (delarbete IV), en registerstudie av alla svenskar i åldern 45-84 år, visades att personer som behandlas med både antidepressiva och diabetesläkemed hade större risk att insjukna i en första hjärtinfarkt jämfört med dem som inte hade något av dessa läkemedel eller läkemedel ur endera gruppen. Denna risk var störst hos yngre individer 45-64 år. Det fanns en påtaglig könsskillnad och det var de yngre kvinnorna som löpte störst risk.

Sammanfattningsvis är huvudfynden i denna avhandling att riskfaktorer för hjärt-kärlsjukdom hos de äldsta i befolkningen är svårvärderade eftersom de inte kan kopplas till sjukdom och prognos på samma sätt som hos yngre. 


\section{ACKNOWLEDGEMENTS}

'I'm not lost for I know where I am. But however, where I am may be lost' A.A. Milnes

My warmest gratitude to all of you that contributed to this thesis, keeping me on track, especially to:

Professor Carl Johan Östgren, my head supervisor, for your encouragement and devotion, your unfailing interest, knowledge and ability to offer just the right piece of advice for me to be able to go on with the work uninterrupted.

My supervisor, Magnus Falk, associate professor and GP, for your support and ability to see the whole picture, always taking the time to talk about anything from working conditions to research method choices.

Professor Jan Marcusson at the geriatrics department, my supervisor, for inviting me to be a part of your project, and your encouragement to go on when I was hesitating in the very beginning. Without that, this thesis would certainly not have happened.

Associate professor Ewa Wressle at the geriatrics department, for interesting discussions, great assistance and swift replies whenever I had questions about the ELSA85 database.

Christina Lannerling, Unit of Research and Development in Primary Care, Futurum, Jönköping for your knowledge of the SHADES database and never failing to reply instantly to my numerous questions.

Professor Lars H. Lindholm, Umeå University and chairman of the National Research School in General Practice, for your priceless guidance and help, getting me in contact with the head of the Framingham study and organising the pre-doc stay at the George Institute for Global Health in Sydney.

Professor John Chalmers, the George Institute for Global Health, for your interest and your solid knowledge and experience, for friendly encouragement 
and trust in my ability, and for your warm welcome to me and my family in Sydney.

Associate professor Hisatomi Arima, the George Institute for Global Health, for your patience, expert knowledge, statistical guidance and lectures.

Dr Karin Festin, statistician at Linköping University for statistical guidance and your great ability to understand the essence of my many questions and to offer, to a physician, perfectly understandable explanations.

Associate professor Ann-Britt Wiréhn, Research and Development Unit in Local Health Care, for blood, sweat, tears and laughter. In other words, your encouragement and your patience with our gigantic database.

All my co-authors for stimulating discussions and great advice.

Catharina Linderoth and Kajsa Bendtsen, Linköping University and Maria Boström, the National Research School in General Practice for excellent administrative assistance.

My superiors Kerstin Lindqvist and Jens Aagaard, my colleagues and the staff at Mantorp's primary care centre for your interest and your patience with the various challenges research work brings to clinical practice.

All study participants.

Least but by no means last, my wonderful husband Carl and lovely children Clara, Axel and Arvid, for your patience and support, for your positive attitude and for gladly coming with me to Sydney. Also, to my mother and father Eva and Kjell Rådholm for all your help, and likewise to my parents in law Agneta Hulterström and Gunnar Fredriksson.

THANK YOU! 


\section{REFERENCES}

1. Suzman R, Beard JR, Boerma T, Chatterji S: Health in an ageing world-what do we know? Lancet 2015, 385(9967):484-486.

2. United Nations DoEaSA, Population Division (2013). World Population Ageing 2013. ST/ESA/SER.A/348.

3. Statistics Sweden, Population statistics. http://www.scb.se/en.

4. Bendjilali N, Hsueh WC, He Q, Willcox DC, Nievergelt CM, Donlon TA, Kwok PY, Suzuki M, Willcox BJ: Who are the Okinawans? Ancestry, genome diversity, and implications for the genetic study of human longevity from a geographically isolated population. The journals of gerontology Series A, Biological sciences and medical sciences 2014, 69(12):1474-1484.

5. Newman $A B$, Murabito JM: The epidemiology of longevity and exceptional survival. Epidemiologic reviews 2013, 35:181-197.

6. Willcox DC, Willcox BJ, Wang NC, He Q, Rosenbaum M, Suzuki M: Life at the extreme limit: phenotypic characteristics of supercentenarians in Okinawa. The journals of gerontology Series A, Biological sciences and medical sciences 2008, 63(11):1201-1208.

7. Willcox DC, Willcox BJ, He Q, Wang NC, Suzuki M: They really are that old: a validation study of centenarian prevalence in Okinawa. The journals of gerontology Series A, Biological sciences and medical sciences 2008, 63(4):338-349.

8. Terry DF, Wilcox M, McCormick MA, Lawler E, Perls TT: Cardiovascular advantages among the offspring of centenarians. The journals of gerontology Series A, Biological sciences and medical sciences 2003, 58(5):M425-431.

9. World Health Organisation, The Top 10 Causes of Death. http://who.int/mediacentre/factsheets/fs310/en/. 2014.

10. Kannel WB, D'Agostino RB, Silbershatz $\mathrm{H}$ : Blood pressure and cardiovascular morbidity and mortality rates in the elderly. American heart journal 1997, 134(4):758-763.

11. Huang Y, Cai X, Li Y, Su L, Mai W, Wang S, Hu Y, Wu Y, Xu D: Prehypertension and the risk of stroke: a meta-analysis. Neurology 2014, 82(13):1153-1161. 
12. Albarwani S, Al-Siyabi S, Tanira MO: Prehypertension: Underlying pathology and therapeutic options. World journal of cardiology 2014, 6(8):728-743.

13. Cardiovascular disease, chronic kidney disease, and diabetes mortality burden of cardiometabolic risk factors from 1980 to 2010: a comparative risk assessment. The lancet Diabetes \& endocrinology 2014, 2(8):634-647.

14. Marengoni A, Angleman S, Melis R, Mangialasche F, Karp A, Garmen A, Meinow B, Fratiglioni L: Aging with multimorbidity: a systematic review of the literature. Ageing research reviews 2011, 10(4):430-439.

15. Santoni G, Angleman S, Welmer AK, Mangialasche F, Marengoni A, Fratiglioni L: Age-related variation in health status after age 60. PloS one 2015, 10(3):e0120077.

16. Di Angelantonio E, Kaptoge S, Wormser D, Willeit P, Butterworth AS, Bansal N, O'Keeffe LM, Gao P, Wood AM, Burgess S et al: Association of Cardiometabolic Multimorbidity With Mortality. JAMA : the journal of the American Medical Association 2015, 314(1):52-60.

17. Global Health Observatory (GHO) data. who.int/gho/ncd/risk_factors/en WHO 2015.

18. Blomstrand A, Blomstrand C, Ariai N, Bengtsson C, Bjorkelund C: Stroke incidence and association with risk factors in women: a 32year follow-up of the Prospective Population Study of Women in Gothenburg. BMJ open 2014, 4(10):e005173.

19. Ezzati M, Henley SJ, Thun MJ, Lopez AD: Role of smoking in global and regional cardiovascular mortality. Circulation 2005, 112(4):489-497.

20. Havranek EP, Mujahid MS, Barr DA, Blair IV, Cohen MS, Cruz-Flores S, Davey-Smith G, Dennison-Himmelfarb CR, Lauer MS, Lockwood DW et al: Social Determinants of Risk and Outcomes for Cardiovascular Disease: A Scientific Statement From the American Heart Association. Circulation 2015.

21. Kivimaki M, Jokela M, Nyberg ST, Singh-Manoux A, Fransson EI, Alfredsson L, Bjorner JB, Borritz M, Burr H, Casini A et al: Long working hours and risk of coronary heart disease and stroke: a systematic review and meta-analysis of published and unpublished data for 603838 individuals. Lancet 2015.

22. Kastorini CM, Milionis HJ, Georgousopoulou E, Kalantzi K, Nikolaou V, Vemmos KN, Goudevenos JA, Panagiotakos DB: Defining the Path Between Social and Economic Factors, Clinical and Lifestyle Determinants, and Cardiovascular Disease. Global heart 2015. 
23. Eriksson MK, Franks PW, Eliasson M: A 3-year randomized trial of lifestyle intervention for cardiovascular risk reduction in the primary care setting: the Swedish Bjorknas study. PloS one 2009, 4(4):e5195.

24. Long GH, Simmons RK, Norberg M, Wennberg P, Lindahl B, Rolandsson O, Griffin SJ, Weinehall L: Temporal shifts in cardiovascular risk factor distribution. American journal of preventive medicine 2014, 46(2):112-121.

25. Perk J, De Backer G, Gohlke H, Graham I, Reiner Z, Verschuren M, Albus C, Benlian P, Boysen G, Cifkova R et al: European Guidelines on cardiovascular disease prevention in clinical practice (version 2012). The Fifth Joint Task Force of the European Society of Cardiology and Other Societies on Cardiovascular Disease Prevention in Clinical Practice (constituted by representatives of nine societies and by invited experts). European heart journal 2012, 33(13):1635-1701.

26. VIP $i$ vården? - Om utmaningar $i$ vården av personer med kronisk sjukdom, Myndigheten för vårdanalys, Rapport 2014:2, ISBN 978-9187213-24-3 http://www.vardanalys.se. 2014.

27. White PD: The heart in hypertension since the days of Richard Bright. Canadian Medical Association journal 1946, 54:129-136.

28. Kotchen TA: Historical trends and milestones in hypertension research: a model of the process of translational research. Hypertension 2011, 58(4):522-538.

29. Booth J: A short history of blood pressure measurement. Proceedings of the Royal Society of Medicine 1977, 70(11):793-799.

30. Nilsson PM: [Hypertension--a hot topic for writers of Lakartidningen's articles. From observations and diet to surgery and extensive clinical trials]. Lakartidningen 2004, 101(18):1598-1603. - in Swedish.

31. Kylin E: Studien über das Hypertonie-HyperglykämieHyperurikämisyndrom. Zentralblatt für innere Medizin 1923(7):105-127.

32. Moser M: Historical perspectives on the management of hypertension. J Clin Hypertens (Greenwich) 2006, 8(8 Suppl 2):15-20; quiz 39.

33. Kannel WB, Schwartz MJ, McNamara PM: Blood pressure and risk of coronary heart disease: the Framingham study. Diseases of the chest 1969, 56(1):43-52.

34. Ariesen MJ, Claus SP, Rinkel GJ, Algra A: Risk factors for intracerebral hemorrhage in the general population: a systematic review. Stroke; a journal of cerebral circulation 2003, 34(8):2060-2065.

35. Vasan RS, Beiser A, Seshadri S, Larson MG, Kannel WB, D'Agostino RB, Levy D: Residual lifetime risk for developing hypertension in 
middle-aged women and men: The Framingham Heart Study. JAMA : the journal of the American Medical Association 2002, 287(8):1003-1010.

36. Turnheim K: When drug therapy gets old: pharmacokinetics and pharmacodynamics in the elderly. Experimental gerontology 2003, 38(8):843-853.

37. Kithas PA, Supiano MA: Practical recommendations for treatment of hypertension in older patients. Vascular health and risk management 2010, 6:561-569.

38. Benetos A, Rossignol P, Cherubini A, Joly L, Grodzicki T, Rajkumar C, Strandberg TE, Petrovic M: Polypharmacy in the Aging Patient: Management of Hypertension in Octogenarians. JAMA : the journal of the American Medical Association 2015, 314(2):170-180.

39. 2013 ESH/ESC Guidelines for the Management of Arterial Hypertension. Blood pressure 2013, 22(4):193-278.

40. Weber MA, Schiffrin EL, White WB, Mann S, Lindholm LH, Kenerson JG, Flack JM, Carter BL, Materson BJ, Ram CV et al: Clinical practice guidelines for the management of hypertension in the community: a statement by the American Society of Hypertension and the International Society of Hypertension. J Clin Hypertens (Greenwich) 2014, 16(1):14-26.

41. Fagard R: Reappraisal of the European guidelines on hypertension management: the European Society of Hypertension Task Force document: a short review. Polskie Archiwum Medycyny Wewnetrznej 2010, 120(1-2):31-35.

42. Benetos A, Labat C, Rossignol P, Fay R, Rolland Y, Valbusa F, Salvi P, Zamboni M, Manckoundia P, Hanon O et al: Treatment With Multiple Blood Pressure Medications, Achieved Blood Pressure, and Mortality in Older Nursing Home Residents: The PARTAGE Study. JAMA internal medicine 2015.

43. Midlov P, Ekesbo R, Johansson L, Gerward S, Persson K, Nerbrand C, Hedblad B: Barriers to adherence to hypertension guidelines among GPs in southern Sweden: a survey. Scandinavian journal of primary health care 2008, 26(3):154-159.

44. Beckett NS, Peters R, Fletcher AE, Staessen JA, Liu L, Dumitrascu D, Stoyanovsky V, Antikainen RL, Nikitin Y, Anderson C et al: Treatment of hypertension in patients $\mathbf{8 0}$ years of age or older. The New England journal of medicine 2008, 358(18):1887-1898. 
45. Mattila K, Haavisto M, Rajala S, Heikinheimo R: Blood pressure and five year survival in the very old. Br Med J (Clin Res Ed) 1988, 296(6626):887-889.

46. Molander L, Lovheim H, Norman T, Nordstrom P, Gustafson Y: Lower systolic blood pressure is associated with greater mortality in people aged 85 and older. Journal of the American Geriatrics Society 2008, 56(10):1853-1859.

47. Qiu C, von Strauss E, Winblad B, Fratiglioni L: Decline in blood pressure over time and risk of dementia: a longitudinal study from the Kungsholmen project. Stroke; a journal of cerebral circulation 2004, 35(8):1810-1815.

48. Verghese J, Lipton RB, Hall CB, Kuslansky G, Katz MJ: Low blood pressure and the risk of dementia in very old individuals. Neurology 2003, 61(12):1667-1672.

49. Turnheim K: Drug therapy in the elderly. Experimental gerontology 2004, 39(11-12):1731-1738.

50. Bejan-Angoulvant $T$, Saadatian-Elahi M, Wright JM, Schron EB, Lindholm LH, Fagard R, Staessen JA, Gueyffier F: Treatment of hypertension in patients 80 years and older: the lower the better? A meta-analysis of randomized controlled trials. Journal of hypertension 2010, 28(7):1366-1372.

51. Kyle UG, Genton L, Hans D, Karsegard VL, Michel JP, Slosman DO, Pichard C: Total body mass, fat mass, fat-free mass, and skeletal muscle in older people: cross-sectional differences in 60-year-old persons. Journal of the American Geriatrics Society 2001, 49(12):1633-1640.

52. Lindholm LH, Carlberg B, Samuelsson O: Should beta blockers remain first choice in the treatment of primary hypertension? A metaanalysis. Lancet 2005, 366(9496):1545-1553.

53. von Moltke LL, Greenblatt DJ, Romach MK, Sellers EM: Cognitive toxicity of drugs used in the elderly. Dialogues in clinical neuroscience 2001, 3(3):181-190.

54. The Swedish Council on Technology Assessment in Health Care: Summary and conclusions of the SBU Report: How can drug consumption among elderly be improved?: a systematic review: May 2009, Rapportnr: 193 • ISBN 978-91-85413-27-0 • ISSN 1400-1403, 2009. - in Swedish.

55. Jansson SP: A Longitudinal Study of Diabetes Mellitus. With Special Reference to Incidence and Prevalence, and to Determinants of Macrovascular Complications and Mortality. 2014. 
56. Bailey CJ, Day C.: Metformin: its botanical background. Practical Diabetes International 2004, 21(3):115-117.

57. Gaede P, Lund-Andersen H, Parving HH, Pedersen O: Effect of a multifactorial intervention on mortality in type 2 diabetes. The New England journal of medicine 2008, 358(6):580-591.

58. Lee $\mathrm{WL}$, Cheung $\mathrm{AM}$, Cape $\mathrm{D}$, Zinman B: Impact of diabetes on coronary artery disease in women and men: a meta-analysis of prospective studies. Diabetes care 2000, 23(7):962-968.

59. World Health Organisation. Diabetes. Fact sheet $\mathbf{N}^{\circ} 312$ http://www.who.int/mediacentre/factsheets/fs312/en/. 2015.

60. Swedish National Diabetes Register, Annual report 2013. 2014.

61. Danaei G, Finucane MM, Lu Y, Singh GM, Cowan MJ, Paciorek CJ, Lin JK, Farzadfar F, Khang YH, Stevens GA et al: National, regional, and global trends in fasting plasma glucose and diabetes prevalence since 1980: systematic analysis of health examination surveys and epidemiological studies with 370 country-years and 2.7 million participants. Lancet 2011, 378(9785):31-40.

62. Jansson SP, Fall K, Brus O, Magnuson A, Wandell P, Ostgren CJ, Rolandsson $\mathrm{O}$ : Prevalence and incidence of diabetes mellitus: a nationwide population-based pharmaco-epidemiological study in Sweden. Diabetic medicine : a journal of the British Diabetic Association 2015.

63. Jansson SP, Andersson DK, Svardsudd K: Prevalence and incidence rate of diabetes mellitus in a Swedish community during 30 years of follow-up. Diabetologia 2007, 50(4):703-710.

64. Migdal A, Yarandi SS, Smiley D, Umpierrez GE: Update on diabetes in the elderly and in nursing home residents. Journal of the American Medical Directors Association 2011, 12(9):627-632 e622.

65. Lofgren UB, Rosenqvist U, Lindstrom $\mathrm{T}$, Hallert $\mathrm{C}$, Nystrom FH: Diabetes control in Swedish community dwelling elderly: more often tight than poor. Journal of internal medicine 2004, 255(1):96-101.

66. Sjoblom P, AndersTengblad, Lofgren UB, Lannering C, Anderberg N, Rosenqvist U, Molstad S, Ostgren CJ: Can diabetes medication be reduced in elderly patients? An observational study of diabetes drug withdrawal in nursing home patients with tight glycaemic control. Diabetes research and clinical practice 2008, 82(2):197-202.

67. Ray KK, Seshasai SR, Wijesuriya S, Sivakumaran R, Nethercott S, Preiss $D$, Erqou S, Sattar N: Effect of intensive control of glucose on cardiovascular outcomes and death in patients with diabetes 
mellitus: a meta-analysis of randomised controlled trials. Lancet 2009, 373(9677):1765-1772.

68. Ostgren CJ, Sundstrom J, Svennblad B, Lohm L, Nilsson PM, Johansson G: Associations of $\mathrm{HbA1c}$ and educational level with risk of cardiovascular events in 32,871 drug-treated patients with Type 2 diabetes: a cohort study in primary care. Diabetic medicine : a journal of the British Diabetic Association 2013, 30(5):e170-177.

69. Zoungas S, Patel A, Chalmers J, de Galan BE, Li Q, Billot L, Woodward M, Ninomiya T, Neal B, MacMahon S et al: Severe hypoglycemia and risks of vascular events and death. The New England journal of medicine 2010, 363(15):1410-1418.

70. Lindstrom T, Jorfeldt L, Tegler L, Arnqvist HJ: Hypoglycaemia and cardiac arrhythmias in patients with type 2 diabetes mellitus. Diabetic medicine : a journal of the British Diabetic Association 1992, 9(6):536-541.

71. Vårdprogram, Äldre med diabetes, för dig som arbetar inom vårdboende och hemsjukvård, Sveriges Kommuner och Landsting, webbutik.skl.se, ISBN 978-91-7585-036-8, 2014.

72. Hendrikx T: Catch Atrial Fibrillation, Prevent Stroke. Detection of atrial fibrillation and other arrhythmias with short intermittent ECG. 2015.

73. Krikler DM: The foxglove, 'The old woman from Shropshire' and William Withering. Journal of the American College of Cardiology 1985, 5(5 Suppl A):3A-9A.

74. Pirmohamed M, Kamali F, Daly AK, Wadelius M: Oral anticoagulation: a critique of recent advances and controversies. Trends in pharmacological sciences 2015, 36(3):153-163.

75. Heeringa J, van der Kuip DA, Hofman A, Kors JA, van Herpen G, Stricker BH, Stijnen T, Lip GY, Witteman JC: Prevalence, incidence and lifetime risk of atrial fibrillation: the Rotterdam study. Eur Heart J 2006, 27(8):949-953.

76. Kannel WB, Wolf PA, Benjamin EJ, Levy D: Prevalence, incidence, prognosis, and predisposing conditions for atrial fibrillation: population-based estimates. Am J Cardiol 1998, 82(8A):2N-9N.

77. De Sisti A, Leclercq JF, Halimi F, Fiorello P, Bertrand C, Attuel P: Evaluation of time course and predicting factors of progression of paroxysmal or persistent atrial fibrillation to permanent atrial fibrillation. Pacing and clinical electrophysiology : PACE 2014, 37(3):345355. 
78. Mozaffarian D, Furberg CD, Psaty BM, Siscovick D: Physical activity and incidence of atrial fibrillation in older adults: the cardiovascular health study. Circulation 2008, 118(8):800-807.

79. Mukamal KJ, Tolstrup JS, Friberg J, Jensen G, Gronbaek M: Alcohol consumption and risk of atrial fibrillation in men and women: the Copenhagen City Heart Study. Circulation 2005, 112(12):1736-1742.

80. Heeringa J, Hoogendoorn EH, van der Deure WM, Hofman A, Peeters RP, Hop WC, den Heijer M, Visser TJ, Witteman JC: High-normal thyroid function and risk of atrial fibrillation: the Rotterdam study. Arch Intern Med 2008, 168(20):2219-2224.

81. Friberg J, Scharling H, Gadsboll N, Jensen GB: Sex-specific increase in the prevalence of atrial fibrillation (The Copenhagen City Heart Study). Am J Cardiol 2003, 92(12):1419-1423.

82. Ostgren CJ, Merlo J, Rastam L, Lindblad U: Atrial fibrillation and its association with type 2 diabetes and hypertension in a Swedish community. Diabetes Obes Metab 2004, 6(5):367-374.

83. Du X, Ninomiya T, de Galan B, Abadir E, Chalmers J, Pillai A, Woodward M, Cooper M, Harrap S, Hamet P et al: Risks of cardiovascular events and effects of routine blood pressure lowering among patients with type 2 diabetes and atrial fibrillation: results of the ADVANCE study. Eur Heart J 2009, 30(9):1128-1135.

84. Iguchi Y, Kimura K, Kobayashi K, Aoki J, Terasawa Y, Sakai K, Uemura J, Shibazaki K: Relation of atrial fibrillation to glomerular filtration rate. Am J Cardiol 2008, 102(8):1056-1059.

85. Schmidt M, Rieber J, Daccarett M, Marschang H, Sinha AM, Biggar P, Jung P, Ketteler M, Brachmann J, Rittger H: Relation of recurrence of atrial fibrillation after successful cardioversion to renal function. $A m$ J Cardiol 2010, 105(3):368-372.

86. Merghani A, Malhotra A, Sharma S: The U-shaped relationship between exercise and cardiac morbidity. Trends in cardiovascular medicine 2015.

87. Sharma S, Merghani A, Mont L: Exercise and the heart: the good, the bad, and the ugly. European heart journal 2015, 36(23):1445-1453.

88. Chiang CE, Naditch-Brule L, Murin J, Goethals M, Inoue H, O'Neill J, Silva-Cardoso J, Zharinov O, Gamra H, Alam S et al: Distribution and risk profile of paroxysmal, persistent, and permanent atrial fibrillation in routine clinical practice: insight from the real-life global survey evaluating patients with atrial fibrillation 
international registry. Circulation Arrhythmia and electrophysiology 2012, 5(4):632-639.

89. Lotze U, Liebetrau J, Malsch I, Fruhwirt B, Rothhagen B, Kharatyan N, Neubauer K: Medical treatment of patients with atrial fibrillation aged over 80 years in daily clinical practice: influence of age and CHADS(2) score. Arch Gerontol Geriatr 2010, 50(1):36-41.

90. Schoonderwoerd BA, Smit MD, Pen L, Van Gelder IC: New risk factors for atrial fibrillation: causes of 'not-so-lone atrial fibrillation'. Europace 2008, 10(6):668-673.

91. Wolf PA, Abbott RD, Kannel WB: Atrial fibrillation as an independent risk factor for stroke: the Framingham Study. Stroke 1991, 22(8):983988.

92. Rojas JI, Zurru MC, Romano M, Patrucco L, Cristiano E: Acute ischemic stroke and transient ischemic attack in the very old--risk factor profile and stroke subtype between patients older than 80 years and patients aged less than 80 years. Eur J Neurol 2007, 14(8):895-899.

93. Ferro JM: Cardioembolic stroke: an update. Lancet Neurol 2003, 2(3):177188.

94. Howard PA: New oral anticoagulants for stroke prevention in atrial fibrillation: more choices bring more challenges. Hospital pharmacy 2013, 48(5):366-371.

95. Vasishta S, Toor F, Johansen A, Hasan M: Stroke prevention in atrial fibrillation: physicians' attitudes to anticoagulation in older people. Arch Gerontol Geriatr 2001, 33(3):219-226.

96. Yamashita Y, Hamatani Y, Esato M, Chun YH, Tsuji H, Wada H, Hasegawa K, Abe M, Lip GY, Akao M: Clinical characteristics and outcomes in extreme elderly (age $>/=85$ ) Japanese patients with atrial fibrillation: The Fushimi AF Registry. Chest 2015.

97. Mant JW: Pro: 'Warfarin should be the drug of choice for thromboprophylaxis in elderly patients with atrial fibrillation'. Why warfarin should really be the drug of choice for stroke prevention in elderly patients with atrial fibrillation. Thrombosis and haemostasis 2008, 100(1):14-15.

98. Hylek EM: Contra: 'Warfarin should be the drug of choice for thromboprophylaxis in elderly patients with atrial fibrillation'. Caveats regarding use of oral anticoagulant therapy among elderly patients with atrial fibrillation. Thrombosis and haemostasis 2008, 100(1):16-17. 
99. Senoo K, Lane DA, Lip GY: Oral anticoagulants for stroke prevention in atrial fibrillation. Current problems in cardiology 2014, 39(9):319-344.

100. Tulner LR, Kuper IM, van Campen JP, Mac Gillavry MR, Kwa VI, Koks $\mathrm{CH}$, Beijnen JH, Brandjes DP: Contraindications for Anticoagulation in Older Patients with Atrial Fibrillation; A Narrative Review. Curr Drug Saf 2010.

101. Fang MC: Antithrombotic therapy for the treatment of atrial fibrillation in the elderly. J Interv Card Electrophysiol 2009, 25(1):19-23.

102. Mant J, Hobbs FD, Fletcher K, Roalfe A, Fitzmaurice D, Lip GY, Murray E: Warfarin versus aspirin for stroke prevention in an elderly community population with atrial fibrillation (the Birmingham Atrial Fibrillation Treatment of the Aged Study, BAFTA): a randomised controlled trial. Lancet 2007, 370(9586):493-503.

103. Connolly SJ, Ezekowitz MD, Yusuf S, Eikelboom J, Oldgren J, Parekh A, Pogue J, Reilly PA, Themeles E, Varrone J et al: Dabigatran versus warfarin in patients with atrial fibrillation. The New England journal of medicine 2009, 361(12):1139-1151.

104. Sardar P, Chatterjee S, Chaudhari S, Lip GY: New oral anticoagulants in elderly adults: evidence from a meta-analysis of randomized trials. Journal of the American Geriatrics Society 2014, 62(5):857-864.

105. Mookadam M, Shamoun FE, Mookadam F: Novel Anticoagulants in Atrial Fibrillation: A Primer for the Primary Physician. Journal of the American Board of Family Medicine : JABFM 2015, 28(4):510-522.

106. Eikelboom JW, Wallentin L, Connolly SJ, Ezekowitz M, Healey JS, Oldgren J, Yang S, Alings M, Kaatz S, Hohnloser SH et al: Risk of bleeding with 2 doses of dabigatran compared with warfarin in older and younger patients with atrial fibrillation: an analysis of the randomized evaluation of long-term anticoagulant therapy (RE-LY) trial. Circulation 2011, 123(21):2363-2372.

107. Larsson T: Behandling av depression genom tiderna, http://www.netdoktor.se/depression/artiklar/behandling-avdepression-genom-tiderna/ 2005. - in Swedish.

108. Moussavi S, Chatterji S, Verdes E, Tandon A, Patel V, Ustun B: Depression, chronic diseases, and decrements in health: results from the World Health Surveys. Lancet 2007, 370(9590):851-858.

109. Magnil M, Gunnarsson R, Bjorkstedt K, Bjorkelund C: Prevalence of depressive symptoms and associated factors in elderly primary care patients: a descriptive study. Primary care companion to the Journal of clinical psychiatry 2008, 10(6):462-468. 
110. Copeland JR, Beekman AT, Braam AW, Dewey ME, Delespaul P, Fuhrer R, Hooijer C, Lawlor BA, Kivela SL, Lobo A et al: Depression among older people in Europe: the EURODEP studies. World Psychiatry 2004, 3(1):45-49.

111. Licht-Strunk E, van der Windt DA, van Marwijk HW, de Haan M, Beekman AT: The prognosis of depression in older patients in general practice and the community. A systematic review. Family practice 2007, 24(2):168-180.

112. Taylor WD: Clinical practice. Depression in the elderly. The New England journal of medicine 2014, 371(13):1228-1236.

113. Kohler S, Buntinx F, Palmer K, van den Akker M: Depression, vascular factors, and risk of dementia in primary care: a retrospective cohort study. Journal of the American Geriatrics Society 2015, 63(4):692-698.

114. Bartoli F, Lillia N, Lax A, Crocamo C, Mantero V, Carra G, Agostoni E, Clerici M: Depression after stroke and risk of mortality: a systematic review and meta-analysis. Stroke research and treatment 2013, 2013:862978.

115. Brown LC, Majumdar SR, Johnson JA: Type of antidepressant therapy and risk of type 2 diabetes in people with depression. Diabetes research and clinical practice 2008, 79(1):61-67.

116. Yoon JM, Cho EG, Lee HK, Park SM: Antidepressant use and diabetes mellitus risk: a meta-analysis. Korean journal of family medicine 2013, 34(4):228-240.

117. Bryan C, Songer T, Brooks MM, Rush AJ, Thase ME, Gaynes B, Balasubramani GK, Trivedi MH, Fava M, Wisniewski SR: The impact of diabetes on depression treatment outcomes. General hospital psychiatry 2010, 32(1):33-41.

118. Lustman PJ, Anderson RJ, Freedland KE, de Groot M, Carney RM, Clouse RE: Depression and poor glycemic control: a meta-analytic review of the literature. Diabetes Care 2000, 23(7):934-942.

119. Bhattacharjee S, Bhattacharya R, Kelley GA, Sambamoorthi U: Antidepressant use and new-onset diabetes: a systematic review and meta-analysis. Diabetes/metabolism research and reviews 2013, 29(4):273284.

120. Lustman PJ, Freedland KE, Griffith LS, Clouse RE: Fluoxetine for depression in diabetes: a randomized double-blind placebocontrolled trial. Diabetes care 2000, 23(5):618-623.

121. Knol MJ, Derijks HJ, Geerlings MI, Heerdink ER, Souverein PC, Gorter $\mathrm{KJ}$, Grobbee DE, Egberts AC: Influence of antidepressants on 
glycaemic control in patients with diabetes mellitus. Pharmacoepidemiology and drug safety 2008, 17(6):577-586.

122. Seitz DP, Adunuri N, Gill SS, Gruneir A, Herrmann N, Rochon P: Antidepressants for agitation and psychosis in dementia. The Cochrane database of systematic reviews 2011(2):CD008191.

123. Feldman M, Cryer B, McArthur KE, Huet BA, Lee E: Effects of aging and gastritis on gastric acid and pepsin secretion in humans: a prospective study. Gastroenterology 1996, 110(4):1043-1052.

124. Kyle UG, Genton L, Hans D, Karsegard L, Slosman DO, Pichard C: Agerelated differences in fat-free mass, skeletal muscle, body cell mass and fat mass between $\mathbf{1 8}$ and $\mathbf{9 4}$ years. European journal of clinical nutrition 2001, 55(8):663-672.

125. Teasdale G, Jennett B: Assessment of coma and impaired consciousness. A practical scale. Lancet 1974, 2(7872):81-84.

126. Wilkinson GR: The effects of diet, aging and disease-states on presystemic elimination and oral drug bioavailability in humans. Advanced drug delivery reviews 1997, 27(2-3):129-159.

127. Walter-Sack I, Klotz U: Influence of diet and nutritional status on drug metabolism. Clinical pharmacokinetics 1996, 31(1):47-64.

128. Moore AR, O'Keeffe ST: Drug-induced cognitive impairment in the elderly. Drugs \& aging 1999, 15(1):15-28.

129. Maas MB, Nemeth AJ, Rosenberg NF, Kosteva AR, Guth JC, Liotta EM, Prabhakaran S, Naidech AM: Subarachnoid extension of primary intracerebral hemorrhage is associated with poor outcomes. Stroke; a journal of cerebral circulation 2013, 44(3):653-657.

130. Jansen PA, Brouwers JR: Clinical pharmacology in old persons. Scientifica 2012, 2012:723678.

131. Hovstadius B, Petersson G, Hellstrom L, Ericson L: Trends in inappropriate drug therapy prescription in the elderly in Sweden from 2006 to 2013: assessment using national indicators. Drugs $\mathcal{E}$ aging 2014, 31(5):379-386.

132. Poulain MH, Anne: Central Population Registers as a Source of Demographic Statistics in Europe Population-E 2013, 68(2):183-212.

133. Den svenska folkbokföringens historia under tre sekler http://www.skatteverket.se - in Swedish.

134. EuroQol--a new facility for the measurement of health-related quality of life. The EuroQol Group. Health Policy 1990, 16(3):199-208.

135. Rabin R, de Charro F: EQ-5D: a measure of health status from the EuroQol Group. Annals of medicine 2001, 33(5):337-343. 
136. Dolan P: Modeling valuations for EuroQol health states. Med Care 1997, 35(11):1095-1108.

137. Whitworth JA: 2003 World Health Organization (WHO)/International Society of Hypertension (ISH) statement on management of hypertension. Journal of hypertension 2003, 21(11):1983-1992.

138. Physical status: the use and interpretation of anthropometry. Report of a WHO Expert Committee. World Health Organization technical report series 1995, 854:1-452.

139. Cockcroft DW, Gault MH: Prediction of creatinine clearance from serum creatinine. Nephron 1976, 16(1):31-41.

140. Surawicz B, Childers R, Deal BJ, Gettes LS, Bailey JJ, Gorgels A, Hancock EW, Josephson M, Kligfield P, Kors JA et al: AHA/ACCF/HRS recommendations for the standardization and interpretation of the electrocardiogram: part III: intraventricular conduction disturbances: a scientific statement from the American Heart Association Electrocardiography and Arrhythmias Committee, Council on Clinical Cardiology; the American College of Cardiology Foundation; and the Heart Rhythm Society. Endorsed by the International Society for Computerized Electrocardiology. J Am Coll Cardiol 2009, 53(11):976-981.

141. Mason JW, Hancock EW, Gettes LS, Bailey JJ, Childers R, Deal BJ, Josephson M, Kligfield $\mathrm{P}$, Kors JA, Macfarlane $\mathrm{P}$ et al: Recommendations for the standardization and interpretation of the electrocardiogram: part II: Electrocardiography diagnostic statement list: a scientific statement from the American Heart Association Electrocardiography and Arrhythmias Committee, Council on Clinical Cardiology; the American College of Cardiology Foundation; and the Heart Rhythm Society: endorsed by the International Society for Computerized Electrocardiology. Circulation 2007, 115(10):1325-1332.

142. Pewsner D, Juni P, Egger M, Battaglia M, Sundstrom J, Bachmann LM: Accuracy of electrocardiography in diagnosis of left ventricular hypertrophy in arterial hypertension: systematic review. BMJ 2007, 335(7622):711.

143. Devereux RB, Bella J, Boman K, Gerdts E, Nieminen MS, Rokkedal J, Papademetriou V, Wachtell K, Wright J, Paranicas $\mathrm{M}$ et al: Echocardiographic left ventricular geometry in hypertensive patients with electrocardiographic left ventricular hypertrophy: The LIFE Study. Blood Press 2001, 10(2):74-82. 
144. Sokolow M, Lyon TP: The ventricular complex in left ventricular hypertrophy as obtained by unipolar precordial and limb leads. $A m$ Heart J 1949, 37(2):161-186.

145. Gage BF, Waterman AD, Shannon W, Boechler M, Rich MW, Radford MJ: Validation of clinical classification schemes for predicting stroke: results from the National Registry of Atrial Fibrillation. JAMA 2001, 285(22):2864-2870.

146. Rietbrock S, Heeley E, Plumb J, van Staa T: Chronic atrial fibrillation: Incidence, prevalence, and prediction of stroke using the Congestive heart failure, Hypertension, Age $>75$, Diabetes mellitus, and prior Stroke or transient ischemic attack (CHADS2) risk stratification scheme. Am Heart J 2008, 156(1):57-64.

147. Lip GY, Nieuwlaat R, Pisters R, Lane DA, Crijns HJ: Refining clinical risk stratification for predicting stroke and thromboembolism in atrial fibrillation using a novel risk factor-based approach: the euro heart survey on atrial fibrillation. Chest 2010, 137(2):263-272.

148. Downton JH: Falls in the elderly. London, UK, Edward Arnold; 64-80: 128-301993.

149. Folstein MF, Folstein, S.E., McHugh, P.R., Fanjiang, G. : Mini-Mental State Examination user's guide. . Odessa, FL: Psychological Assessment Resources 2001.

150. Brott T, Adams HP, Jr., Olinger CP, Marler JR, Barsan WG, Biller J, Spilker J, Holleran R, Eberle R, Hertzberg V et al: Measurements of acute cerebral infarction: a clinical examination scale. Stroke; a journal of cerebral circulation 1989, 20(7):864-870.

151. van Swieten JC, Koudstaal PJ, Visser MC, Schouten HJ, van Gijn J: Interobserver agreement for the assessment of handicap in stroke patients. Stroke; a journal of cerebral circulation 1988, 19(5):604-607.

152. Bamford JM, Sandercock PA, Warlow CP, Slattery J: Interobserver agreement for the assessment of handicap in stroke patients. Stroke 1989, 20(6):828.

153. Grubb A, Nyman U, Bjork J, Lindstrom V, Rippe B, Sterner G, Christensson A: Simple cystatin C-based prediction equations for glomerular filtration rate compared with the modification of diet in renal disease prediction equation for adults and the Schwartz and the Counahan-Barratt prediction equations for children. Clinical chemistry 2005, 51(8):1420-1431.

154. Gupta V, Lipsitz LA: Orthostatic hypotension in the elderly: diagnosis and treatment. The American journal of medicine 2007, 120(10):841-847. 
155. Rubenstein LZ, Harker J, Guigoz Y, Vellas B: Comprehensive geriatric assessment (CGA) and the MNA: an overview of CGA, nutritional assessment, and development of a shortened version of the MNA. Nestle Nutrition workshop series Clinical \& performance programme 1999, 1:101-115; discussion 115-106.

156. The Swedish Prescribed Drug Register (National Board of Health and Welfare), Läkemedelsregistret (Socialstyrelsen) - in Swedish. http://www.socialstyrelsen.se/register/halsodataregister/lakemedelsreg istret.

157. Official statistics of Sweden, Myocardial infarctions in Sweden 19872008, http://www.socialstyrelsen.se/statistics, 2010 - in Swedish.

158. Savitz SI, Lew R, Bluhmki E, Hacke W, Fisher M: Shift analysis versus dichotomization of the modified Rankin scale outcome scores in the NINDS and ECASS-II trials. Stroke; a journal of cerebral circulation 2007, 38(12):3205-3212.

159. Fitzmaurice D: Atrial fibrillation and coagulation: who and when? Blood Rev 2009, 23(6):241-244.

160. Benjamin EJ, Wolf PA, D'Agostino RB, Silbershatz H, Kannel WB, Levy $\mathrm{D}$ : Impact of atrial fibrillation on the risk of death: the Framingham Heart Study. Circulation 1998, 98(10):946-952.

161. Burstrom K, Johannesson M, Diderichsen F: Swedish population health-related quality of life results using the EQ-5D. Quality of life research: an international journal of quality of life aspects of treatment, care and rehabilitation 2001, 10(7):621-635.

162. Berg J, Lindgren $P$, Nieuwlaat $R$, Bouin $O$, Crijns $H$ : Factors determining utility measured with the EQ-5D in patients with atrial fibrillation. Quality of life research : an international journal of quality of life aspects of treatment, care and rehabilitation 2010, 19(3):381-390.

163. Sprigg N, Selby J, Fox L, Berge E, Whynes D, Bath PM: Very low quality of life after acute stroke: data from the Efficacy of Nitric Oxide in Stroke trial. Stroke; a journal of cerebral circulation 2013, 44(12):3458-3462.

164. Carod-Artal FJ, Egido JA: Quality of life after stroke: the importance of a good recovery. Cerebrovasc Dis 2009, 27 Suppl 1:204-214.

165. Bergersen H, Froslie KF, Stibrant Sunnerhagen K, Schanke AK: Anxiety, depression, and psychological well-being 2 to 5 years poststroke. Journal of stroke and cerebrovascular diseases : the official journal of National Stroke Association 2010, 19(5):364-369.

166. Lincoln NB, Brinkmann N, Cunningham S, Dejaeger E, De Weerdt W, Jenni W, Mahdzir A, Putman K, Schupp W, Schuback B et al: Anxiety 
and depression after stroke: a 5 year follow-up. Disability and rehabilitation 2013, 35(2):140-145.

167. Staessen JA, Richart T, Birkenhager WH: Less atherosclerosis and lower blood pressure for a meaningful life perspective with more brain. Hypertension 2007, 49(3):389-400.

168. Stenestrand U, Wijkman M, Fredrikson M, Nystrom FH: Association between admission supine systolic blood pressure and 1-year mortality in patients admitted to the intensive care unit for acute chest pain. JAMA : the journal of the American Medical Association 2010, 303(12):1167-1172.

169. Dong H-J, Wressle, E., Marcusson, J.: Unaltered image of health maintenance: An observation of non-participants in a Swedish cohort study of $\mathbf{8 5}$ to $\mathbf{8 6}$ year olds. The Journal of Frailty \& Aging 2015, 4(2):93-99.

170. Davies EA, O'Mahony MS: Adverse drug reactions in special populations - the elderly. British journal of clinical pharmacology 2015.

171. Scherrer JF, Garfield LD, Chrusciel T, Hauptman PJ, Carney RM, Freedland KE, Owen R, True WR, Lustman PJ: Increased risk of myocardial infarction in depressed patients with type 2 diabetes. Diabetes care 2011, 34(8):1729-1734.

172. van Asch CJ, Luitse MJ, Rinkel GJ, van der Tweel I, Algra A, Klijn CJ: Incidence, case fatality, and functional outcome of intracerebral haemorrhage over time, according to age, sex, and ethnic origin: a systematic review and meta-analysis. Lancet neurology 2010, 9(2):167176.

173. Införandet av vårdval i primärvården, Slutredovisning, The National Board of Health and Welfare, Article 2010-02-10, http://www.socialstyrelsen.se - in Swedish.

174. Låt den rätte komma in - Hur har tillgängligheten påverkats av apoteksomregleringen, vårdvalet samt vårdgarantin och Kömiljarden? Myndigheten för vårdanalys http://www.vardanalys.se Rapport 2014:3 - in Swedish.

175. Åtgärdsförslag för att utveckla vården och omsorgen om de mest sjuka äldre, Primärvård och korttidsboende - vad behöver förändras? The National Board of Health and Welfare, Article 2015-2-45, http://www.socialstyrelsen.se/ - in Swedish.

176. Ludvigsson JF, Andersson E, Ekbom A, Feychting M, Kim JL, Reuterwall C, Heurgren $\mathrm{M}$, Olausson PO: External review and 
validation of the Swedish national inpatient register. BMC public health 2011, 11:450. 


\section{Papers}

The articles associated with this thesis have been removed for copyright reasons. For more details about these see:

http://urn.kb.se/resolve?urn=urn:nbn:se:liu:diva-121286 